\section{Pengaruh CAR, FDR, Dan BOPO Terhadap ROA Pada Bank Syariah Di Indonesia}

\author{
Intan Rika Yuliana dan Sinta Listari
}

Program Studi Manajemen Fakultas Bisnis Institut Bisnis Dan Informatika Kesatuan

E-Mail : sinta.listari@ibik.ac.id
Financial Ratio of Sharia Banking in Indonesia

\begin{abstract}
Banking companies, including Islamic banking, need to avoid problems that can cause financial failure, which can make the bank unable to carry out its business operations and may end up in bankruptcy, so that the level of soundness of the bank based on risk must always be monitored. Therefore, banks must maintain their financial ratios in accordance with Bank Indonesia decisions and maintain their performance. So analyzing the effect of the Capital Adequacy Ratio (CAR), Financing to Deposit Ratio (FDR), and the Ratio of Operating Costs to Operating Income (BOPO) on Return On Assets (ROA) in Islamic Banks is considered very important. This study aims to analyze the effect of Capital Adequacy Ratio (CAR), Financing to Deposit Ratio (FDR), and Operational Costs on Operating Income (BOPO) on Return On Assets (ROA) at Islamic Commercial Banks in Indonesia. This research includes quantitative research and the type of data used is secondary data. The data used in this study is the ratio of CAR, FDR, BOPO, and ROA for the period 2014-2019 which was obtained from the annual Financial Statements on the official website of each bank. The population in this study were 14 Islamic Commercial Banks in Indonesia. After passing the purposive sampling stage, there were 6 samples of Sharia Commercial Banks that were suitable for use, namely BCA Syariah, BNI Syariah, Bank Mega Syariah, Bank Muamalat Indonesia, Bank Panin Dubai Syariah and BRI Syariah. The analytical method used in this research is Multiple Linear Regression Analysis. The results of the partial study with the t-test showed that the CAR and FDR variables had a positive and significant effect on the ROA of Islamic commercial banks. While the BOPO variable has a negative and significant effect on the ROA of Islamic commercial banks. And the results of the $f$ test show that the CAR, FDR, and BOPO variables together have a significant influence on the ROA of Islamic commercial banks. The predictive ability of these three variables on $R O A$ is $82.7 \%$, the remaining $17.3 \%$ is explained by other variables outside of this research.
\end{abstract}

Keywords: Capital Adequacy Ratio (CAR), Financing to Deposit Ratio (FDR), Operating Expenses per Operating Income (BOPO), Return On Assets (ROA)

\begin{abstract}
ABSTRAK
Perusahaan perbankan termasuk perbankan syariah perlu menghindari timbulnya masalah yang dapat menyebabkan kegagalan secara finansial, yang dapat membuat bank tidak dapat menjalankan kegiatan operasional usahanya dan dapat berakhir pada kebangkrutan, sehingga tingkat kesehatan bank berdasarkan risiko harus selalu dipantau. Oleh karena itu bank harus menjaga rasio-rasio keuangannya disesuaikan dengan keputusan Bank Indonesia serta menjaga kinerjanya. Maka menganalisis pengaruh Capital Adequacy Ratio (CAR), Financing to Deposit Ratio (FDR), dan Rasio Biaya Operasional terhadap Pendapatan Operasional (BOPO) terhadap Return On Assets (ROA) pada Bank Syariah dirasa sangatlah penting. Penelitian ini bertujuan untuk menganalisis pengaruh Capital Adequacy Ratio (CAR), Financing to Deposit Ratio (FDR), dan Biaya Operasional terhadap Pendapatan Operasional (BOPO) terhadap Return On Asset (ROA) pada Bank Umum Syariah di Indonesia. Penelitian ini termasuk penelitian kuantitatif dan jenis data yang digunakan adalah data sekunder. Data yang digunakan dalam penelitian ini adalah data rasio CAR, FDR, BOPO, dan ROA periode 2014-2019 yang diperoleh
\end{abstract}

Accepted: JULI 2021

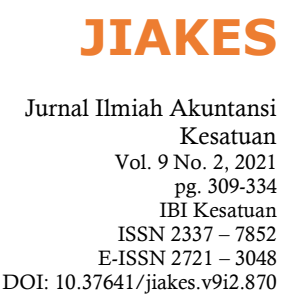


Financial Ratio of Sharia Banking in Indonesia dari Laporan Keuangan tahunan pada situs resmi masing-masing bank. Populasi dalam penelitian ini adalah 14 Bank Umum Syariah di Indonesia. Setelah melewati tahap purposive sampling, terdapat 6 sampel Bank Umum Syariah yang layak digunakan yaitu BCA Syariah, BNI Syariah, Bank Mega Syariah, Bank Muamalat Indonesia, Bank Panin Dubai Syariah dan BRI Syariah. Metode analisis yang digunakan dalam penelitian ini adalah Analisis Regresi Linier Berganda. Hasil penelitian secara parsial dengan uji t menunjukkan bahwa variabel CAR dan FDR berpengaruh positif dan signifikan terhadap ROA bank umum syariah. Sedangkan variabel BOPO berpengaruh negatif dan signifikan terhadap ROA bank umum syariah. Dan hasil uji f menunjukkan bahwa variabel CAR, FDR, dan BOPO secara bersama-sama mempunyai pengaruh yang signifikan terhadap ROA bank umum syariah. Kemampuan prediksi dari ketiga variabel tersebut terhadap ROA adalah sebesar $82,7 \%$, sisanya $17,3 \%$ dijelaskan oleh variabel lain diluar peneltian ini.

Kata kunci : Capital Adequacy Ratio (CAR), Financing to Deposit Ratio (FDR), Biaya Operasional terhadap Pendapatan Operasional (BOPO), Return On Asset (ROA)

\section{PENDAHULUAN}

Sebagai sebuah perusahaan yang bergerak di bidang jasa, usaha perbankan diantaranya meliputi tiga kegiatan, yaitu menghimpun dana, menyalurkan dana, serta memberikan jasa bank lainnya. Kegiatan menghimpun dan menyalurkan dana menjadi kegiatan yang utama, sedangkan kegiatan lainnya ialah berbagai jasa pendukung yang fungsinya untuk mendukung kelancaran kegiatan utama (Pinasti \& Mustikawati, 2018, 127).

Dalam Undang-Undang No. 7 Tahun 1992 tentang perbankan sebagaimana yang saat ini telah diubah dengan Undang-Undang No. 10 Tahun 1998 disebutkan bahwa:

"Bank adalah badan usaha yang menghimpun dana dari masyarakat dalam bentuk simpanan dan menyalurkannya kepada masyarakat dalam bentuk kredit dan atau bentukbentuk lainnya dalam rangka meningkatkan taraf hidup rakyat banyak"

Dalam menjalankan aktivitasnya, dapat dikatakan bahwa bank berfungsi sebagai financial intermediary atau lembaga perantara keuangan antara pihak yang surplus atau memiliki kelebihan dana dengan pihak yang defisit atau kekurangan dana (Bilian \& Purwanto, 2017, 155).

Menurut Ismail $(2011,26)$ pengertian dari bank syariah adalah bank yang tidak menggunakan sistem bunga dalam sistem operasionalnya, akan tetapi menggunakan prinsip dasar sesuai dengan syariah islam. Oleh karena itu, dalam menentukan imbalannya, baik imbalan yang diberikan maupun diterima, bank syariah tidak menggunakan sistem bunga, akan tetapi menggunakan konsep imbal hasil sesuai dengan akad yang diperjanjikan.

Menurut Usman $(2009,7)$ setelah diundangkannya Undang-undang Nomor 10 Tahun 1998, perkembangan bank syariah di Indonesia semakin pesat, yaitu ditandai dengan berdirinya bank syariah baru dengan sistem dual banking (dual banking system).

Di dalam Undang-Undang Nomor 10 Tahun 1998 tentang Perbankan, lembaga keuangan bank aturannya telah berkembang dengan menggunakan dual banking system (sistem perbankan ganda) undang-undang ini ialah perubahan dari Undang-Undang Nomor 7 Tahun 1992 tentang Perbankan (Yanthiani, 2019, 1293).

Dual banking system yang dianut di Indonesia menyebabkan adanya dua jenis bank, bank konvensional yang melaksanakan kegiatan usaha secara konvensional, dan bank syariah yang melaksanakan usaha berdasarkan prinsip syariah (Shomad, 2012, 116).

Menurut Yanthiani $(2019,1294)$ dengan adanya perubahan regulasi tersebut, bankbank umum konvensional tentunya akan mendapatkan kesempatan yang luas untuk memberikan layanan syariah melalui Islamic Window dengan membentuk Unit Usaha Syariah terlebih dahulu. Dengan demikian, ada dua macam bentuk pendirian bank 
syariah di Indonesia yaitu murni mendirikan bank Syariah atau bank umum konvensional yang memberikan layanan syariah.

Menurut Yulihapsari dkk $(2017,102)$ perbankan syariah eksistensinya semakin meningkat di Indonesia sejak adanya Undang-Undang No. 21 Tahun 2008 tentang Perbankan Syariah karena dapat memberikan landasan operasi yang lebih jelas bagi bank syariah. Hal ini dapat dilihat dari perkembangan perbankan syariah di Indonesia, di mana pada tahun 1992 di Indonesia hanya terdapat satu Bank Umum Syariah yang beroperasi yaitu Bank Muamalat Indonesia serta 9 BPRS. Masyarakat menerima dengan baik kehadiran bank syariah di Indonesia, hal ini terlihat dari jumlah jaringan kantor Bank Umum Syariah, Unit Usaha Syariah dan Bank Pembiayaan Rakyat Syariah yang terus berkembang pada tabel di bawah ini:

Financial Ratio of Sharia Banking in Indonesia

Tabel 1. Jaringan Kantor Perbankan Syariah

\begin{tabular}{l|ccccccc}
\hline \multirow{2}{*}{ Kategori } & \multicolumn{7}{|c}{ Jumlah Jaringan Kantor } \\
\cline { 2 - 8 } & 2006 & 2008 & 2010 & 2012 & 2014 & 2016 & 2019 \\
\hline Bank Umum Syariah & 3 & 5 & 11 & 11 & 12 & 13 & 14 \\
Unit Usaha Syariah & 20 & 27 & 23 & 24 & 22 & 21 & 20 \\
BPRS & 105 & 131 & 150 & 158 & 163 & 166 & 164 \\
\hline
\end{tabular}

Sumber : SPS (2019), SPS (2015), SPS (2013), SPS (2006)

Berdasarkan tabel 1., tampak bahwa jumlah bank yang melakukan kegiatan usaha berdasarkan prinsip syariah mengalami peningkatan. Hal ini terlihat dari jumlah bank umum syariah sebelum tahun 2008 dimana hanya terdapat 3 Bank Umum Syariah pada tahun 2006, namun setelah disusunnya Undang-Undang No 21 tahun 2008 tentang perbankan syariah, pada tahun 2010 jumlah bank umum syariah mengalami peningkatan menjadi 11 dan pada tahun berikutnya jumlah Bank Umum Syariah dan terus bertambah hingga pada tahun 2019 jumlahnya menjadi 14 bank. Bank Pembiayaan Rakyat Syariah (BPRS) juga mengalami peningkatan tiap tahunnya, dimana kenaikan atau penambahan BPRS paling tinggi terjadi pada tahun 2010, yakni sebesar 19 BPRS dari tahun 2008 sebanyak 131, menjadi 150 pada tahun 2010. Pada Unit Usaha Syariah (UUS), walaupun sebelumnya terjadi penurunan pada tahun 2010 menjadi 23 UUS, namun pada tahun 2012 kemudian mengalami peningkatan menjadi 24 UUS

Pertumbuhan bank syariah yang tinggi menunjukkan bahwa daya tarik perbankan syariah yang juga tinggi karena mayoritas penduduk di Indonesia beragama Islam dan komitmen pemerintah Indonesia guna mengembangkan perbankan syariah telah dibuktikan dengan disusunnya Undang-Undang No.21 Tahun 2008 tentang Perbankan Syariah (Nuha \& Mulazid, 2018, 69).

Menurut Pratiwi $(2018,2)$ perkembangan yang terjadi pada perbankan syariah menjadikan persaingan antar bank syariah semakin ketat. Oleh karena itu perusahaan perbankan harus dapat menunjukkan kinerja keungan yang optimal agar dapat bersaing di pasar industri perbankan.

Bisnis perbankan adalah bisnis kepercayaan, oleh karena itu kinerja bank merupakan hal yang sangat penting, sehingga bank harus mampu menunjukkan kredibilitasnya agar semakin banyak masyarakat yang bertransaksi di bank tersebut, salah satunya melalui peningkatan profitabilitas. Di samping itu pada bank syariah, hubungan antara bank dengan nasabahnya bukan hubungan debitur dengan kreditur, melainkan hubungan kemitraan (partnership) antara penyandang dana (shohibul maal) dengan pengelola dana (mudharib). Oleh karena itu, tingkat laba bank syariah tidak saja berpengaruh terhadap tingkat bagi hasil untuk para pemegang saham tetapi juga berpengaruh terhadap hasil yang dapat diberikan kepada nasabah penyimpan dana. Itulah sebabnya penting bagi bank syariah untuk terus meningkatkan profitabilitasnya (Arifin, 2009, 56).

Profitabilitas bank yang didapatkan, sebagai petunjuk atau indikator utama guna mengukur tingkat kinerja atau performance pengelolaan bank (Putera, 2019, 110). Profitabilitas menunjukkan kemampuan bank dalam menghasilkan laba secara efektif 
Financial Ratio of Sharia Banking in Indonesia

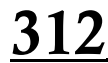

dan efisien. Kemampuan perusahaan dalam menghasilkan laba dapat dijadikan tolok ukur kinerja perusahaan tersebut. Semakin tinggi profitabilitas yang diperoleh suatu bank, maka kinerja bank tersebut pun semakin baik (Pratiwi, 2012, 4).

Ada dua rasio yang biasanya dipakai untuk mengukur kinerja bank, yaitu Return On Assets (ROA) dan return on equity (ROE). Return On Assets atau biasa disebut ROA adalah rasio yang mengukur tingkat optimalisasi aset yang dimiliki untuk menghasilkan keuntungan. Nilai minimal ROA yang ditetapkan Bank Indonesia minimal 1,5\%. Mampu memenuhi kewajiban kepada pemegang saham, penilaian kinerja manajemen, dan meningkatkan daya tarik investor untuk menanamkan modalnya. Itulah sebabnya bank berusaha keras untuk memperoleh keuntungan. Dengan nilai ROA yang tinggi, maka bank dapat memberikan pembiayaan untuk memperoleh pendapatan (Riyadi S, 2018, 1018). ROE didefinisikan sebagai perbandingan antara pendapatan bersih (net income) dengan rata-rata modal (average equity) atau investasi para pemilik bank (Arifin, 2009, 71).

ROE dapat menunjukkan kemampuan manajemen bank untuk mendapatkan net income dengan mengelola modal yang tersedia, sedangkan ROA menunjukkan kemampuan manajemen bank dalam mengelola aset yang dimiliki untuk menghasilkan income. Dari pengertian tersebut dapat disimpulkan bahwa ROA fokus pada kemampuan perusahaan untuk memperoleh pendapatan dalam operasi perusahaan, sedangkan ROE hanya mengukur income yang diperoleh dari investasi pemilik perusahaan dalam bisnis tersebut (Pratiwi, 2012, 5).

Alasan dipilihnya Return On Assets (ROA) sebagai ukuran kinerja adalah karena ROA digunakan untuk mengukur kemampuan manajemen bank dalam memperoleh keuntungan secara keseluruhan. Semakin besar ROA bank, semakin besar pula tingkat keuntungan yang dicapai bank tersebut dan semakin baik pula posisi bank tersebut dan segi penggunaan aset (Sholihin, 2013, 723).

Penyebab naiknya tingkat profitabilitas bank salah satunya adalah adanya kenaikan dalam perolehan laba bersih. Kenaikan dalam perolehan laba bersih dapat dikarenakan beberapa faktor, diantaranya dikarenakan oleh Capital Adequacy Ratio (CAR), Financing to Deposit Ratio (FDR) dan Beban Operasional terhadap Pendapatan Operasional (BOPO) (Maulida, 2015, 4).

Bank yang sehat ialah bank yang memiliki tingkat kecukupan modal yang baik. Sebab kecukupan modal bank menunjukkan keadaan yang dinyatakan dengan suatu rasio yang disebut rasio kecukupan modal atau Capital Adequacy Ratio (CAR) (Rahmah, 2018, 3). Capital Adequacy Ratio (CAR) disebut dengan rasio kecukupan modal, yang artinya besarnya modal yang dibutuhkan untuk menutupi risiko kerugian finansial yang mungkin timbul dari penggarapan aset yang berisiko. Semakin besar rasio ini maka keuntungan bank juga akan meningkat. Dengan kata lain, semakin kecil risiko sebuah bank, semakin besar pula keuntungan sebuah bank (Amelia, 2015, 232). Berdasarkan ketentuan PBI No. 10/26/PBI/2008 tentang fasilitas pendanaan jangka pendek bagi bank umum, minimum CAR bagi bank Umum adalah sebesar 8\%, ketentuan itu mengacu pada BASEL II. CAR menunjukkan seberapa besar modal bank untuk menunjang kebutuhannya dan semakin besar CAR maka akan semakin besar daya tahan bank yang bersangkutan dan menunjukkan semakin sehat bank tersebut (Wangsawidjaja, 2013, 116).

FDR adalah rasio antara jumlah pembiayaan yang diberikan bank dengan dana yang diterima bank. Batas minimum FDR adalah $80 \%$ dan maksimum 110\% (Syifa, 2018, 170). FDR merupakan salah satu indikator kesehatan likuiditas bank. Penilaian likuiditas merupakan penilaian terhadap kemampuan bank untuk memelihara tingkat likuiditas yang memadai dan kecukupan manajemen rasio likuiditas. Semakin besar jumlah pembiayaan yang disalurkan oleh bank maka akan semakin rendah tingkat likuiditas bank yang bersangkutan. Namun di lain pihak, semakin besar jumlah pembiayaan yang diberikan, diharapkan bank akan mendapatkan return yang tinggi pula. (Wangsawidjaja, 2013, 117) 
Biaya Operasional Pendapatan Operasional (BOPO) merupakan rasio yang digunakan untuk mengukur tingkat efisiensi dan kemampuan bank dalam menjalankan operasinya. Apabila terjadi kenaikan biaya operasional maka akan berdampak pada penurunan laba sebelum pajak yang pada akhirnya akan menurunkan profitabilitas (ROA) pada bank yang bersangkutan (Sitompul, 2019, 235).

Rasio Biaya Operasional adalah perbandingan antara biaya operasional dan pendapatan operasional (BOPO). Rasio biaya operasional digunakan untuk mengukur tingkat efisiensi dan kemampuan bank dalam melakukan kegiatan operasinya (Margaretha, 2007, 62). Semakin kecil rasio ini, maka biaya operasional yang dikeluarkan bank semakin efisien sehingga kemungkinan bank dalam kondisi bermasalah juga menjadi semakin kecil. Semakin besar BOPO maka akan semakin kecil ROA bank, karena laba yang diperoleh bank juga menjadi kecil (Rahmah, 2018, 5).

\section{Tabel 2. Data Pergerakan Rasio Keuangan Bank Umum Syariah di Indonesia tahun} 2014-2019

\begin{tabular}{ccccc}
\hline Periode & ROA & CAR & FDR & BOPO \\
\hline 2014 & $0,41 \%$ & $15,74 \%$ & $86,66 \%$ & $96,97 \%$ \\
2015 & $0,49 \%$ & $15,02 \%$ & $88,03 \%$ & $97,01 \%$ \\
2016 & $0,63 \%$ & $16,63 \%$ & $85,99 \%$ & $96,22 \%$ \\
2017 & $0,63 \%$ & $17,91 \%$ & $79,61 \%$ & $94,91 \%$ \\
2018 & $1,28 \%$ & $20,39 \%$ & $78,53 \%$ & $89,18 \%$ \\
2019 & $1,73 \%$ & $20,59 \%$ & $77,91 \%$ & $84,45 \%$ \\
\hline
\end{tabular}

Sumber : SPS (2019), dan SPS (2015)

Tabel diatas adalah rata-rata variabel penelitian pada bank umum syariah periode 20142019. Dari tabel tersebut terdapat beberapa informasi mengenai adanya fenomena ketidaksesuain teori dengan kejadian empiris yang ada, antara lain:

a. Secara teori hubungan CAR dengan ROA adalah positif. Akan tetapi pada tabel terdapat perbedaan dimana pada tahun 2014-2015 CAR mengalami penurunan dan ROA mengalami Peningkatan. Dan di tahun 2016-2017 CAR mengalami peningkatan, namun ROA tidak mengalami peningkatan.

b. Hubungan antara FDR dengan ROA adalah positif. Akan tetapi pada tahun 20152016 FDR mengalami penurunan, sedangkan ROA mengalami kenaikan. Pada tahun 2016-2017 FDR mengalami penurunan, namun ROA tidak mengalami penurunan. Pada tahun 2017-2018 FDR mengalami penurunan, akan tetapi ROA mengalami kenaikan, dan pada tahun 2018-2019 FDR menurun akan tetapi ROA mengalami kenaikan.

c. Hubungan antara BOPO dengan ROA adalah negatif. Tetapi pada tahun 2014-2015 BOPO mengalami kenaikan dan ROA pun mengalami kenaikan. Pada tahun 20162017 BOPO mengalami penurunan, namun ROA tidak mengalami kenaikan.

Dari fenomena tersebut, dapat ditarik kesimpulan bahwa tidak setiap kejadian empiris sesuai dengan teori yang ada. Oleh karena itu, penulis tertarik untuk melakukan penelitian mengenai Pengaruh CAR, FDR, dan BOPO terhadap ROA pada Bank Syariah di Indonesia.

Berdasarkan latar belakang penelitian yang telah dikemukakan di atas, maka identifikasi masalah dalam penelitian ini adalah :

1. Apakah Capital Adequacy Ratio (CAR) berpengaruh terhadap Return On Assets (ROA)?

2. Apakah Financing To Deposit Ratio (FDR) berpengaruh terhadap Return On Assets (ROA)?

3. Apakah Biaya Operasional terhadap Pendapatan Operasional (BOPO) berpengaruh terhadap Return On Assets (ROA)?

4. Apakah Capital Adequacy Ratio (CAR), Financing to Deposit Ratio (FDR), dan Biaya Operasional Pendapatan Operasional (BOPO) berpengaruh secara bersama - sama terhadap Return On Assets (ROA)?

Financial Ratio of Sharia Banking in Indonesia 
Financial Ratio of Sharia Banking in Indonesia

\section{$\underline{314}$}

Berdasarkan latar belakang yang telah diuraikan, maka dapat disimpulkan tujuan penelitian sebagai berikut:

1. Untuk mengetahui pengaruh Capital Adequacy Ratio (CAR) terhadap Return On Assets (ROA).

2. Untuk mengetahui pengaruh Financing to Deposit Ratio (FDR) terhadap Return On Assets (ROA).

3. Untuk mengetahui pengaruh Biaya Operasional terhadap Pendapatan Operasional (BOPO) terhadap Return On Assets (ROA).

4. Untuk mengetahui pengaruh Capital Adequacy Ratio (CAR), Financing to Deposit Ratio (FDR), dan Biaya Operasional Pendapatan Operasional (BOPO) secara bersamasama terhadap Return On Assets (ROA).

\section{Kerangka Pemikiran Konseptual}

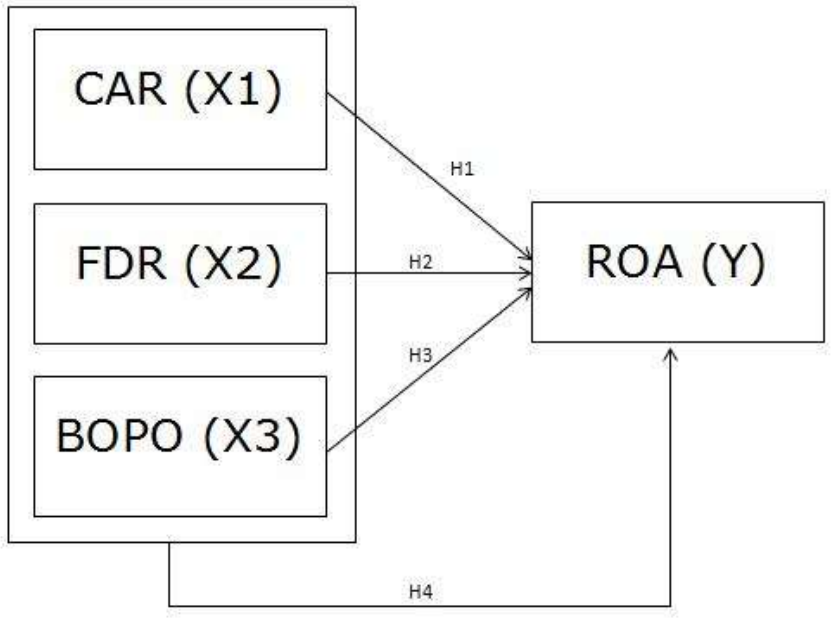

\section{Hipotesis Penelitian}

\section{Gambar 1. Kerangka Pemikiran Konseptual}

Berdasarkan uraian kerangka pemikiran konseptual, maka dapat dirumuskan hipotesis sebagai berikut:

Hipotesis 1 : Capital Adequacy Ratio (CAR) berpengaruh positif terhadap Return On Assets (ROA).

Hipotesis 2 : Financing to Deposit Ratio (FDR) berpengaruh positif terhadap Return On Assets (ROA).

Hipotesis 3 : Biaya Operasional Pendapatan Operasional (BOPO) berpengaruh negatif terhadap Return On Assets (ROA).

Hipotesis 4 : Capital Adequacy Ratio (CAR), Financing to Deposit Ratio (FDR), dan Biaya Operasional Pendapatan Operasional (BOPO) berpengaruh secara bersama-sama terhadap Return On Assets (ROA).

\section{METODOLOGI PENELITIAN}

Dalam penelitian ini, penulis menggunakan jenis penelitian kuantitatif. Penelitian kuantitatif (quantitatif research) adalah suatu metode penelitian yang bersifat induktif, objektif dan ilmiah dimana data yang diperoleh berupa angka-angka (score atau nilai) atau pernyataan-pernyataan yang dinilai, dan dianalisis dengan analisis statistik (Hermawan, 2019 , 16). Objek yang digunakan dalam penelitian ini adalah data CAR, FDR, BOPO dan ROA periode 2014-2019 dan yang dijadikan subjek dalam penelitian ini ialah Bank Umum Syariah yang ada di Indonesia.

Operasionalisasi Variabel

Tabel 3. Operasionalisasi Variabel Penelitian

\begin{tabular}{|l|l|l|l|}
\hline Variabel & Definisi & Indikator & Skala \\
\hline Capital & Rasio kinerja bank untuk & Modal Inti & Rasio
\end{tabular}




\begin{tabular}{|c|c|c|c|}
\hline $\begin{array}{l}\text { Adequacy } \\
\text { Ratio }\left(\mathrm{X}_{1}\right)\end{array}$ & $\begin{array}{l}\text { mengukur kecukupan } \\
\text { modal yang dimiliki bank } \\
\text { untuk menunjang aktiva } \\
\text { yang mengandung atau } \\
\text { menghasilkan risiko } \\
\text { (Margaretha, 2007, 63) }\end{array}$ & $\begin{array}{l}\text { Modal Pelengkap } \\
\text { Aktiva Tertimbang } \\
\text { Menurut Resiko }\end{array}$ & \\
\hline $\begin{array}{l}\text { Financing to } \\
\text { Deposit Ratio } \\
\left(\mathrm{X}_{2}\right)\end{array}$ & $\begin{array}{l}\text { Rasio yang menyatakan } \\
\text { seberapa jauh } \\
\text { kemampuan bank dalam } \\
\text { membayar penarikan } \\
\text { dana yang dilakukan } \\
\text { deposan dengan } \\
\text { Mengandalkan } \\
\text { pembiayaan yang } \\
\text { diberikan sebagai } \\
\text { sumber likuiditas } \\
\text { (Margaretha, 2007, 60). }\end{array}$ & $\begin{array}{l}\text { Total Pembiayaan } \\
\text { Total Dana Pihak } \\
\text { Ketiga }\end{array}$ & Rasio \\
\hline $\begin{array}{l}\text { Biaya } \\
\text { Operasional / } \\
\text { Pendapatan } \\
\text { Operasional } \\
\left(\mathrm{X}_{3}\right)\end{array}$ & $\begin{array}{l}\text { Rasio yang menilai } \\
\text { efisiensi kinerja } \\
\text { operasional bank } \\
\text { dengan cara } \\
\text { membandingkan beban } \\
\text { operasional bank } \\
\text { terhadap pendapatan } \\
\text { yang diterimanya } \\
\text { (Akbar, 2019, 23). }\end{array}$ & $\begin{array}{l}\text { Biaya Operasional } \\
\text { Pendapatan } \\
\text { OPerasional }\end{array}$ & Rasio \\
\hline \begin{tabular}{|l} 
Return On \\
Asstes $(Y)$
\end{tabular} & $\begin{array}{l}\text { Return On Assets (ROA) Rasio } \\
\text { ini digunakan untuk mengukut } \\
\text { kemampuan manajemen bank } \\
\text { dalam memperoleh keuntungan } \\
\text { (laba) secara keseluruhan } \\
\text { (Margaretha, 2007,61) }\end{array}$ & $\begin{array}{l}\text { Laba Sebelum Pajak } \\
\text { Total Aset }\end{array}$ & Rasio \\
\hline
\end{tabular}

\section{Populasi, Unit Penarikan Sampel, dan Teknik Pemilihan Sampel}

Populasi yang digunakan dalam penelitian ini adalah bank umum syariah di Indonesia yaitu sebanyak 14 bank. Sampling unit dalam penelitian ini adalah bank umum syariah yang termasuk kategori buku 2. Menurut POJK No 6/POJK.03/2016, Bank buku 1 adalah bank dengan modal inti sampai kurang dari 1 Triliun rupiah, bank buku 2 adalah bank dengan modal inti paling sedikit satu triliun rupiah sampai dengan kurang dari lima triliun rupiah, bank buku 3 adalah bank dengan modal inti paling sedikit 5 triliun rupiah sampai dengan kurang dari 30 triliun rupiah, bank buku 4 adalah bank dengan modal inti paling sedikit sebesar 30 triliun rupiah. Pemilihan sampel dalam penelitian ini menggunakan metode purposive sampling. Metode ini dipilih berdasarkan pada karakteristik tertentu sesuai dengan tujuan penelitian. Sehingga variable yang digunakan adalah variabel yang sesuai dengan tujuan dari penelitian (Munir, 2018, 93).

Kriteria bank umum syariah yang ditetapkan dalam pemilihan sampel adalah sebagai berikut:

1. Bank Umum Syariah yang terdaftar di Bank Indonesia atau OJK

2. Bank Umum Syariah yang telah beroperasi pada tahun 2014-2019

3. Bank Umum Syariah yang memiliki data lengkap terkait variabel yang digunakan dalam penelitian ini.

4. Bank Umum Syariah yang termasuk kategori buku 2 pada periode penelitian. 
Tabel 4. Pemilihan Sampel Berdasarkan Kriteria Penelitiainancial Ratio of

\begin{tabular}{|c|c|}
\hline$\overline{\text { Kriteria }}$ & $\begin{array}{r}\text { Sharia Penthingin } \\
\text { Bhdonkesia }\end{array}$ \\
\hline Jumlah Bank Umum Syariah di Indonesia & 14 \\
\hline $\begin{array}{l}\text { Jumlah Bank Umum Syariah yang telah beroperasi pada tahun } \\
2014-2019\end{array}$ & 12 \\
\hline $\begin{array}{l}\text { Jumlah Bank Umum Syariah yang memiliki data lengkap terkait } \\
\text { variabel yang digunakan dalam penelitian ini }\end{array}$ & 12 \\
\hline Jumlah Bank Umum Syariah yang termasuk kategori buku 2 & 6 \\
\hline Jumlah sampel bank yang diambil dengan kriteria penelitian & 317 \\
\hline
\end{tabular}

Berdasarkan metode purposive sampling tersebut, tercatat ada 6 sampel yang digunakan dalam penelitian ini. Bank umum syariah yang dijadikan sampel dalam penelitian ini tercatat pada tabel berikut:

Tabel 5. Daftar Bank Umum Syariah Sampel Penelitian periode 2014-2019

\begin{tabular}{|c|l|}
\hline No & Nama Bank Umum Syariah \\
\hline 1 & BCA Syariah \\
\hline 2 & BNI Syariah \\
\hline 3 & Bank Mega Syariah \\
\hline 4 & Bank Muamalat \\
\hline 5 & Bank Panin Dubai Syariah \\
\hline 6 & BRI Syariah \\
\hline
\end{tabular}

Jenis, Sumber, dan Metode Pengumpulan Data

Dalam penelitian ini data yang dipergunakan adalah data sekunder untuk semua variabel yaitu data rasio-rasio keuangan masing-masing Bank Umum Syariah yaitu Capital Adequacy Ratio (CAR), Financing to Deposit Ratio (FDR), Biaya Operasional Pendapatan Operasional (BOPO) dan Return On Assets (ROA). Data sekunder adalah data yang sudah ada dan tidak perlu dikumpulkan sendiri oleh peneliti (Nuha \& Mulazid, 2018, 175). Data sekunder yang terdapat pada penelitian ini berupa data tahunan rasio keuangan dari laporan tahunan perbankan syariah dari tahun 2014 sampai 2019. Data sekunder ini diperoleh dari situs resmi OJK dan situs resmi masing masing bank.

Teknik pengumpulan data dalam penelitian ini adalah sebagai berikut:

(a) Metode dokumentasi, adalah data sekunder yang disimpan dalam bentuk dokumen (catatan elektronik maupun konvensional) (Nuha \& Mulazid, 2018, 175).

(b) Penelitian kepustakaan adalah penelitian untuk memperoleh data sekunder dalam hal ini memperoleh informasi dari buku, jurnal ataupun penelitian terdahulu yang berkaitan dengan masalah yang diteliti (Yanthiani, 2019, 1296).

\section{Metode Pengujian Data}

Menurut Hariwijaya $(2015,118)$ cara untuk menguji kevalidan data yang digunakan tergantung pada jenis data yang digunakan. Apabila jenis data yang digunakan adalah data primer, maka dilakukan uji validitas dan reabilitas. Sedangkan apabila jenis data adalah data sekunder maka digunakan uji asumsi klasik.

Menurut Umar $(2003,103)$ validitas menunjukkan sejauh mana suatu alat pengukur dapat mengukur apa yang ingin diukur. Dan menurut $\operatorname{Umar}(2003,113)$ reabilitas adalah suatu nilai yang menunjukkan konsistensi suatu alat pengukur di dalam mengukur gejala yang sama.

Uji Asumsi Klasik. Uji asumsii klasik adalah persyaratan statistik yang harus dipenuhi pada analisis regresi linier berganda yang berbasis ordinary least square (OLS). Jadi analisis regresi yang tidak berdasarkan OLS tidak memerlukan persyaratan asumsi klasik, misalnya regresi logistik atau regresi ordinal. Demikian juga tidak semua uji asumsi klasik 
harus dilakukan pada analisis regresi linear, misalnya uji multikolinearitas tidak dapat dipergunakan pada analisis regresi linear sederhana dan uji autokorelasi tidak perlu diterapkan pada data cross sectional (Ansofino dkk, 2016, 93). Setidaknya ada empat uji asumsi klasik, diantaranya:
a. Uji Normalitas
b. Uji Multikolineritas
c. Uji Heteroskedastisitas
d. Uji Autokorelasi

\section{Metode Analisis Data dan Pengujian Hipotesis}

Analisis Deskriptif. Analisis statistika deskriptif yaitu metode statistik yang digunakan untuk mengumpulkan, meringkas, menyajikan, dan dapat mendeskripsikan data sehingga dapat memberikan informasi yang berguna. Data yang disajikan dalam statistika deskriptif biasanya dalam bentuk ukuran pemusatan data seperti mean, median, modus (Nisfiannoor, 2009).

Analisis Regresi Linear Berganda. Menurut Suharyadi (2004, 508) Analisis Regresi Berganda digunakan untuk menganalisis besarnya hubungan dan pengaruh variabel independen yang jumlahnya lebih dari dua. Dalam penelitian ini digunakan untuk mengetahui apakah terdapat pengaruh CAR, FDR, dan BOPO terhadap ROA (Return On Assets). Persamaan regresinya yaitu:

$\mathrm{Y}=\alpha+\beta 1 \mathrm{X} 1+\beta 2 \mathrm{X} 2+\beta 3 \mathrm{X} 3+\mathrm{e}$

Keterangan :

$\mathrm{Y}=$ Profitabilitas (Return On Assets)

$\mathrm{X} 1=$ Capital Adequacy Ratio

$\mathrm{X} 2=$ Financing to Deposit Ratio

X3 = Beban Operasional Pendapatan Operasional $\alpha=$ Konstanta

$\mathrm{e}=$ Error

$\beta 1=$ Koefisien regresi 1

$\beta 2=$ Koefisien regresi 2

$\beta 3=$ Koefisien regresi 3

Nilai dari koefisien regresi ini sangat menentukan sebagai dasar analisis. Jika koefisien $b$ bernilai positif $(+)$ maka dapat dikatakan terjadi pengaruh searah antara variabel independen dengan variabel dependen, setiap kenaikan nilai variabel independen akan mengakibatkan kenaikan variabel dependen. Demikian pula sebaliknya, bila koefisien nilai $b$ bernilai negatif(-), hal ini menunjukkan adanya pengaruh negatif dimana kenaikan nilai variabel independen akan mengakibatkan penurunan nilai variabel dependen (Pratiwi, 2012, 66).

\section{Pengujian Hipotesis}

a. Uji t (Parsial). Uji signifikansi parsial atau individual adalah untuk menguji apakah suatu variabel bebas berpengaruh atau tidak terhadap variabel tidak bebas. Uji ini juga bermaksud untuk mengetahui apakah sebuah variabel bebas berpengaruh nyata atau tidak terhadap variabel tidak bebasnya. Suatu variabel akan berpengaruh nyata apabila nilai t-hitung lebih besar dari t-tabel atau lebih kecil dari negatif t-tabel (Suharyadi, 2004, 525). Menurut Riyanto \& Hatmawan (2020, 141) Hipotesis yang digunakan dalam uji ini adalah:

$\mathrm{HO}:$ bi $=0$ artinya, variabel independen tidak berpengaruh terhadap variabel dependen $\mathrm{Hi}:$ bi $\neq 0$ artinya, variabel independen berpengaruh terhadap variabel dependen Pengambilan keputusan dalam uji ini yaitu:

Jika $t_{\text {hitung }}<t_{\text {tabel }}$ atau $-t_{\text {hitung }}>-t_{\text {tabel }}$ atau sig $>0,05(5 \%)$ maka H0 diterima Jika $t_{\text {hitung }} \geq$ $\mathrm{t}_{\text {tabel }}$ atau $-\mathrm{t}_{\text {hitung }} \leq-\mathrm{t}_{\text {tabel }}$ atau sig $\leq 0,05(5 \%)$ maka $\mathrm{H} 0$ ditolak

b. Uji F. Uji F disebut juga Uji signifikansi serentak atau uji global. Uji $F$ adalah uji kemampuan variabel bebas terhadap variabel tidak bebas secara bersama-sama. Uji ini dimaksudkan untuk melihat kemampuan menyeluruh dari variabel bebas, untuk dapat atau mampu menjelaskan tingkah laku atau keragaman variabel tidak bebas. Uji ini 
Financial Ratio of Sharia Banking in Indonesia

\section{8}

juga dimaksudkan untuk mengetahui apakah semua variabel bebas memiliki koefisien regresi sama dengan nol (Suharyadi, 2004, 523).

Menurut Riyanto \& Hatmawan $(2020,313)$ Apabila F hitung $\geq F$ tabel atau sig $\leq \quad 0,05$ maka $\mathrm{H} 0$ ditolak dan apabila $\mathrm{F}$ hitung $<\mathrm{F}$ tabel atau sig $>0,05$ maka Hi diterima.

Berikut ini adalah hipotesis yang digunakan dalam uji ini:

1) $\mathrm{HO}: \mathrm{b}=0$, artinya variabel-variabel independen secara bersama-sama tidak berpengaruh terhadap variabel dependen.

2) Hi: $\beta>0$, artinya, variabel-variabel independen secara bersama-sama berpengaruh terhadap variabel dependen.

c. Uji Koefisien Determinasi $\left(\mathrm{R}^{2}\right)$. Koefisien determinasi didefinisikan sebagai bagian dari keragaman total variabel tak bebas $\mathrm{Y}$ (variabel yang dipengaruhi atau dependen) yang dapat diterangkan atau diperhitungkan oleh keragaman variabel bebas $\mathrm{X}$ (variabel yang mempengaruhi atau independen). Jadi koefisien determinasi adalah kemampuan variabel X (variabel independen) mempengaruhi variabel Y (variabel dependen). Semakin besar koefisien determinasi menunjukkan semakin baik kemampuan X menerangkan Y (Suharyadi, 2004, 465). Nilai koefisien determinasi $\left(R^{2}\right)$ berkisar antara 0-1. Nilai koefisien determinasi $\left(R^{2}\right)$ yang kecil menunjukkan kemempuan variabel-variabel bebas (independen) dalam menjelaskan variabel terikat (dependen) sangat terbatas. Seballiknya, nilai koefisien determinasi $\left(\mathrm{R}^{2}\right)$ yang besar dan mendekati 1 menunjukkan bahwa variabel-variabel bebas (independen) memberikan hampir semua informasi yang dibutuhkan untuk memprediksi variasi variabel terikat (dependen) (Riyanto \& Hatmawan, 2020, 141).

\section{HASIL DAN PEMBAHASAN \\ Hasil Analisis Deskriptif}

Sebelum menguji pengaruh variabel independen terhadap variabel dependen, terlebih dahulu akan ditinjau mengenai deskripsi variabel penelitian dengan analisis statistik deskriptif. Statistik deskriptif dalam penelitian ini memberikan gambaran atau deskripsi mengenai suatu data yang meliputi jumlah sampel $(\mathrm{N})$, nilai minimum, nilai maksimum dan rata-rata (mean) untuk masing-masing variabel.

Penelitian dilakukan dengan mengambil data sekunder bersumber pada situs resmi masing-masing bank priode tahun 2014-2019, adapun data yang diolah adalah sebagai berikut: 
Tabel 6. Data CAR, FDR, BOPO, dan ROA pada Bank Umum Syariah di Indonesia periode 2014-2019

\begin{tabular}{|c|c|c|c|c|c|c|}
\hline \multirow[t]{2}{*}{ No } & \multirow[t]{2}{*}{ BUS } & \multirow[t]{2}{*}{ TAHUN } & $\begin{array}{l}\text { CAR } \\
\text { (X1) } \\
\end{array}$ & $\begin{array}{l}\text { FDR } \\
(\mathrm{X} 2) \\
\end{array}$ & $\begin{array}{c}\text { BOPO } \\
(\mathrm{X} 3) \\
\end{array}$ & $\mathrm{ROA}(\mathrm{Y})$ \\
\hline & & & $\%$ & $\%$ & $\%$ & $\%$ \\
\hline \multirow{6}{*}{1} & \multirow{6}{*}{ BCAS } & 2014 & 29,60 & 91,20 & 92,90 & 0,80 \\
\hline & & 2015 & 34,30 & 91,40 & 92,50 & 1,00 \\
\hline & & 2016 & 36,70 & 90,10 & 92,20 & 1,10 \\
\hline & & 2017 & 29,40 & 88,50 & 87,20 & 1,20 \\
\hline & & 2018 & 24,30 & 89,00 & 87,40 & 1,20 \\
\hline & & 2019 & 38,30 & 91,00 & 87,60 & 1,20 \\
\hline \multirow{6}{*}{2} & \multirow{6}{*}{ BNIS } & 2014 & 16,26 & 92,60 & 89,80 & 1,27 \\
\hline & & 2015 & 15,48 & 91,94 & 89,63 & 1,43 \\
\hline & & 2016 & 14,92 & 84,57 & 86,88 & 1,44 \\
\hline & & 2017 & 20,14 & 80,21 & 87,62 & 1,31 \\
\hline & & 2018 & 19,31 & 79,62 & 85,37 & 1,42 \\
\hline & & 2019 & 18,88 & 74,31 & 81,26 & 1,82 \\
\hline \multirow{6}{*}{3} & \multirow{6}{*}{ BMS } & 2014 & 19,26 & 93,61 & 97,61 & 0,29 \\
\hline & & 2015 & 18,74 & 98,49 & 99,51 & 0,30 \\
\hline & & 2016 & 23,53 & 95,24 & 88,16 & 2,63 \\
\hline & & 2017 & 22,19 & 91,05 & 89,16 & 1,56 \\
\hline & & 2018 & 20,54 & 90,88 & 93,84 & 0,93 \\
\hline & & 2019 & 19,96 & 94,53 & 93,71 & 0,89 \\
\hline \multirow{6}{*}{4} & \multirow{6}{*}{ BMI } & 2014 & 13,91 & 84,14 & 97,33 & 0,17 \\
\hline & & 2015 & 12,00 & 90,30 & 97,36 & 0,20 \\
\hline & & 2016 & 12,74 & 95,13 & 97,76 & 0,22 \\
\hline & & 2017 & 13,62 & 84,41 & 97,68 & 0,11 \\
\hline & & 2018 & 12,34 & 73,18 & 98,24 & 0,08 \\
\hline & & 2019 & 12,42 & 73,51 & 99,50 & 0,05 \\
\hline \multirow{6}{*}{5} & \multirow{6}{*}{ BPDS } & 2014 & 25,69 & 94,04 & 82,58 & 1,99 \\
\hline & & 2015 & 20,30 & 96,43 & 89,29 & 1,14 \\
\hline & & 2016 & 18,17 & 91,99 & 96,17 & 0,37 \\
\hline & & 2017 & 11,51 & 86,95 & 217,40 & $-10,77$ \\
\hline & & 2018 & 23,15 & 88,82 & 99,57 & 0,26 \\
\hline & & 2019 & 14,46 & 96,23 & 97,74 & 0,25 \\
\hline \multirow{6}{*}{6} & \multirow{6}{*}{ BRIS } & 2014 & 12,89 & 93,90 & 99,77 & 0,08 \\
\hline & & 2015 & 13,94 & 84,16 & 93,79 & 0,77 \\
\hline & & 2016 & 20,63 & 81,42 & 91,33 & 0,95 \\
\hline & & 2017 & 20,05 & 71,87 & 95,34 & 0,51 \\
\hline & & 2018 & 29,72 & 75,49 & 95,32 & 0,43 \\
\hline & & 2019 & 25,26 & 80,12 & 96,8 & 0,31 \\
\hline \multicolumn{2}{|c|}{ MIN } & & 11,51 & 71,87 & 81,26 & $-10,77$ \\
\hline \multicolumn{2}{|c|}{$M A X$} & & 38,30 & 98,49 & 217,40 & 2,63 \\
\hline \multicolumn{2}{|c|}{ MEAN } & & 20,41 & 87,51 & 96,26 & 0,53 \\
\hline
\end{tabular}

Sumber: Data sekunder yang diolah
Financial Ratio of

Sharia Banking in Indonesia 319 
Financial Ratio of Sharia Banking in Indonesia

$\underline{320}$

Berdasarkan tabel 6. di atas, dapat diketahui jumlah data yang digunakan dalam penelitian ini adalah sebanyak 36 sampel data yang diperoleh dari laporan keuangan publikasi masing-masing bank umum syariah. Berdasarkan data tersebut diketahui variabel ROA memiliki nilai minimum sebesar $-10,77 \%$ yang diperoleh dari Bank Panin Dubai Syariah pada tahun 2017, hal ini menunjukkan bahwa bank belum maksimal dalam menghasilkan laba, sehingga kerugian yang dialami cukup besar karena nilai ROA negatif. Sedangkan nilai maksimumnya adalah sebesar 2,63\% diperoleh dari Bank Mega Syariah pada tahun 2016. Hal ini menunjukkan bahwa bank sudah cukup optimal dalam menghasilkan laba sehingga mendapat keuntungan. Nilai Rata-rata dari ROA adalah sebesar $0,53 \%$. Hal ini menunjukkan bahwa rasio ROA telah sesuai dengan ketentuan OJK yaitu 0,5\%- 1,25\%. Dengan nilai rata-rata ROA 0,53\% maka tingkat perolehan laba bank umum syariah telah sesuai dengan ketentuan OJK dan termasuk dalam kategori "cukup sehat".

Perkembangan variabel ROA pada periode penelitian dapat dilihat pada grafik berikut ini:

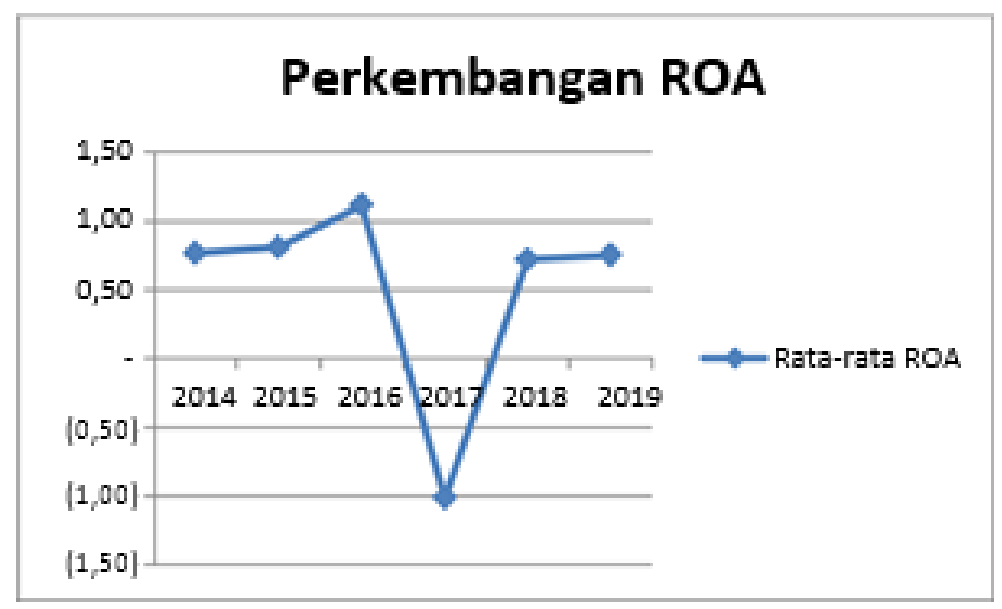

Gambar 2. Perkembangan ROA

Sumber: Data sekunder yang diolah

Berdasarkan gambar 2. di atas dapat diketahui bahwa ROA bank umum syariah cenderung berfluktuatif. Pada tahun 2014, rata-rata ROA sebesar 0,77\% lalu terus mengalami kenaikan hingga tahun 2016 menjadi 1,12\%, kemudian mengalami penurunan yang cukup tajam pada tahun 2017 dan kembali mengalami kenaikan hingga pada tahun 2019 menjadi 0,75\%. Hal ini menunjukkan bahwa profitabilitas bank umum syariah belum stabil.

Rasio CAR terendah adalah sebesar 11,51\% yang diperoleh dari Bank Panin Dubai Syariah pada tahun 2017, hal ini menunjukkan bahwa modal bank sudah baik dan dapat menunjang aktiva yang mengandung atau menghasilkan risiko. Sedangkan nilai maksimum dari variabel CAR adalah sebesar 38,30\% diperoleh dari BCA Syariah pada tahun 2019. Hal ini berarti modal bank telah optimal dalam menunjang aktiva yang mengandung atau menghasilkan risiko. Nilai Rata-rata dari CAR adalah sebesar 20,41\%. Hal ini berarti rasio CAR selama periode penelitian telah memenuhi ketentuan yang ditetapkan pleh OJK yaitu lebih dari 8\%, bahkan melebihi kriteria "sangat sehat" sebesar $12 \%$. Sehingga dapat disimpulkan bahwa rasio kecukupan modal yang dimiliki bank umum syariah dapat dikatakan tinggi.

Perkembangan variabel CAR pada periode penelitian dapat dilihat pada grafik berikut ini: 


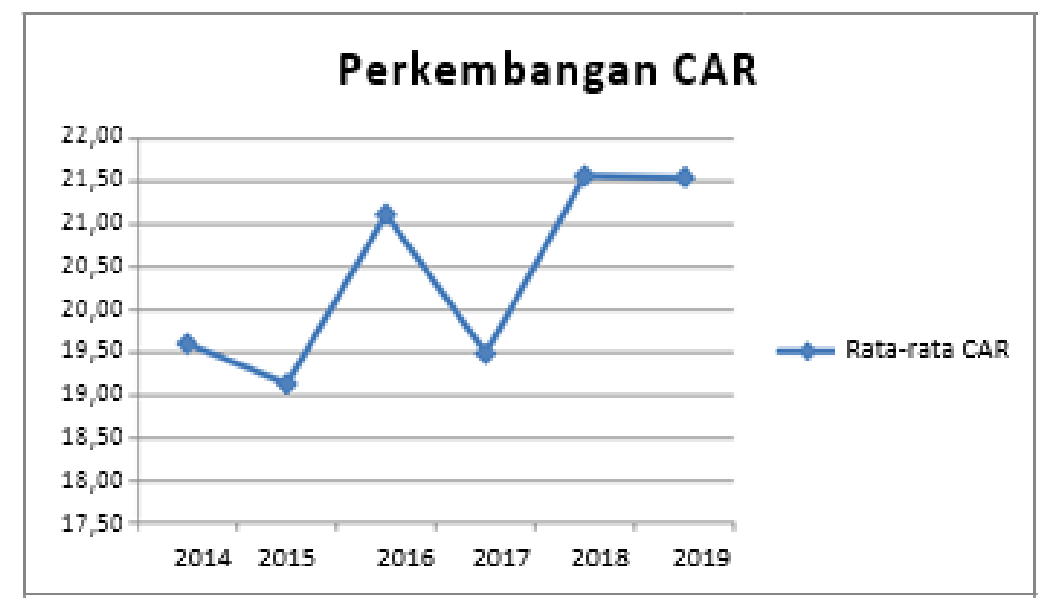

Financial Ratio of

Gambar 3. Perkembangan CAR

Sumber: Data sekunder yang diolah

Berdasarkan gambar 3. Diketahui bahwa CAR bank umum syariah cenderung mengalami fluktuasi setiap tahunnya. Pada tahun 2014, rata-rata CAR sebesar 19,60\% lalu pada tahun 2015 mengalami penurunan menjadi 19,13\%, kemudian pada tahun berikutnya terus mengalami fluktuasi, namun fluktuasi nya cenderung rendah. Hal ini menunjukkan bahwa modal bank umum syariah tidak stabil, tetapi bank umum syariah memiliki tingkat CAR yang termasuk kategori sangat sehat.

Variabel independen FDR memiliki nilai minimum sebesar $71,87 \%$ yang diperoleh daribank BRI Syariah pada tahun 2017, angka tersebut mencerminkan tingkat likuiditas bank yang baik karena bank akan mampu memenuhi kewajibannya kepada pemilik dana pihak ketiga. Sedangkan nilai maksimum dari variabel FDR adalah sebesar 98,49\% yang diperoleh dari Bank Mega Syariah pada tahun 2015. Hal ini menunjukkan tingkat likuiditas bank yang sehat. Nilai Rata-rata dari FDR adalah sebesar 87,51\%. Hal ini menunjukkan rasio FDR menunjukkan kritera "sehat" sesuai dengan ketentuan OJK yaitu dibawah $110 \%$.

Perkembangan variabel FDR pada periode penelitian dapat dilihat pada grafik berikut ini:

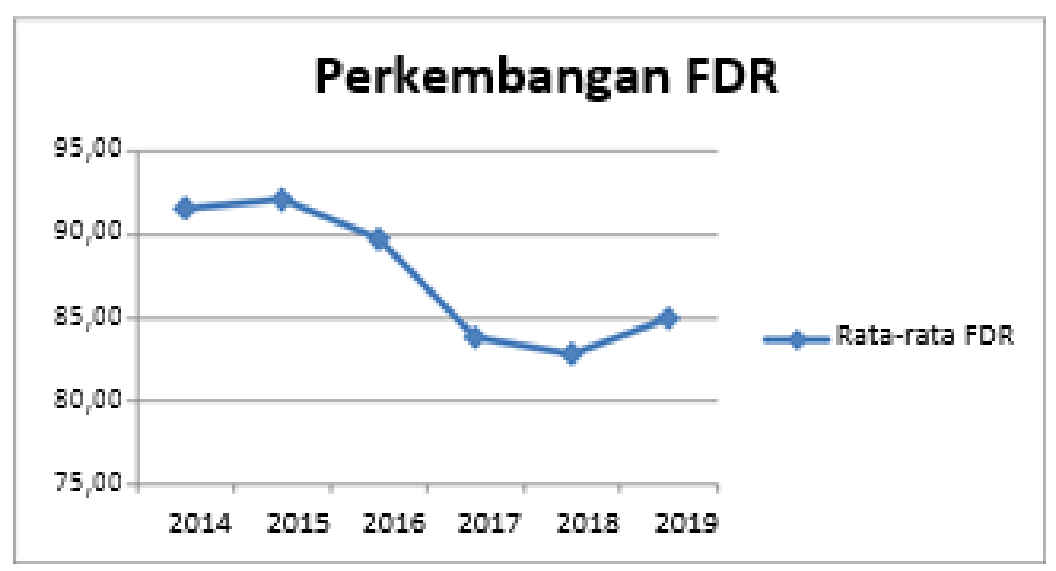

Gambar 4. Perkembangan FDR

Sumber: Data sekunder yang diolah

Berdasarkan gambar 4. di atas diketahui bahwa FDR bank umum syariah cenderung mengalami penurunan. Penurunan terbesar terjadi pada tahun 2017 dimana rasio FDR mengalami penuruan sebesar 5,91\% dari tahun sebelumnya. Pada tahun 2014, rata-rata FDR sebesar 91,58\% lalu pada tahun 2015 turun menjadi $92,12 \%$ dan pada tahun berikutnya terus mengalami penurunan hingga tahun 2018, dan mulai naik kembali di tahun 2019 menjadi 84,95\%. Hal ini menunjukkan bahwa pembiayaan yang disalurkan 
Financial Ratio of Sharia Banking in Indonesia

$\underline{322}$ oleh bank umum syariah cenderung menurun, jumlah pembiayaan yang menurun dapat menurunkan profitabilitas yang didapatkan oleh bank, tetapi di sisi lain juga dapat memperkecil risiko pembiayaan.

Variabel independen BOPO memiliki nilai minimum sebesar $81,26 \%$ yang diperoleh dari BNI Syariah pada tahun 2019, hal ini menunjukkan bahwa bank telah efisien dalam meminimalkan biaya operasional dan meningkatkan pendapatan operasionalnya. Sedangkan nilai maksimum dari variabel BOPO adalah sebesar 217,40\% yang diperoleh dari Bank Panin Dubai Syariah pada tahun 2017. Hal ini menunjukkan bahwa bank belum efisien dalam menekan biaya operasional dan meningkatkan pendapatan operasionalnya. Nilai Rata- rata dari BOPO adalah sebesar 96,26\%. Hal ini menunjukkan rasio BOPO belum memenuhi standar kesehatan bank yang ditentukan oleh OJK yaitu antara $85 \%-87 \%$.

Perkembangan variabel BOPO pada periode penelitian dapat dilihat pada grafik berikut ini:

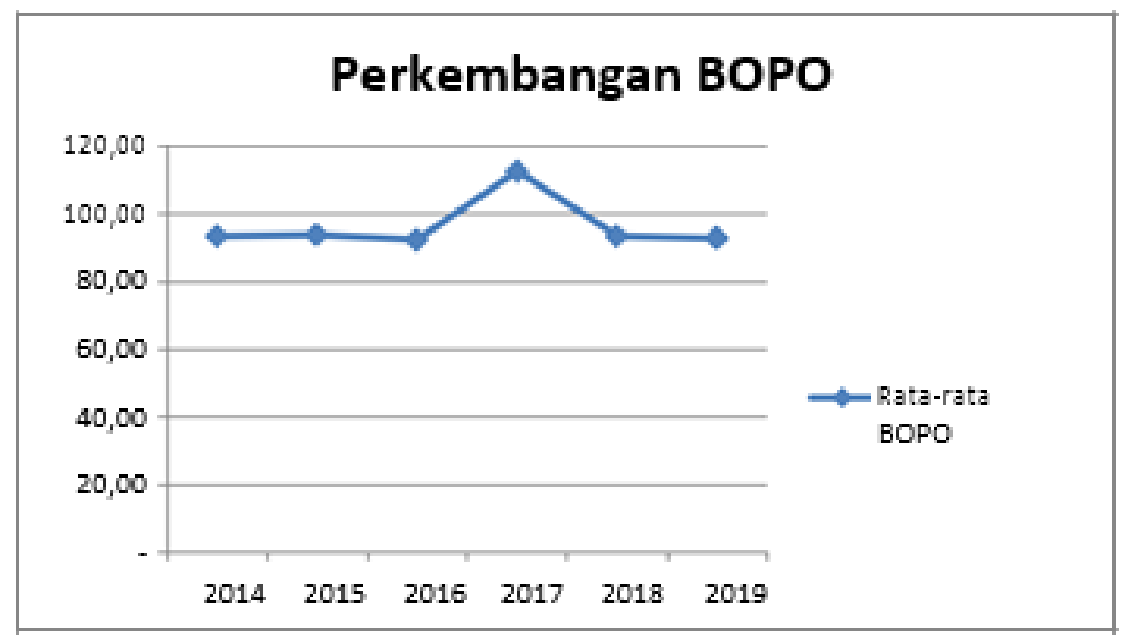

Gambar 5. Perkembangan BOPO

Sumber: Data sekunder yang diolah

Berdasarkan gambar 5. Diketahui bahwa BOPO bank umum syariah mengalami kenaikan dan penurunan selama periode penelitian. Kenaikan terbesar terjadi pada tahun 2017 dimana rasio BOPO naik sebesar 20,32\% dibandingkan dengan tahun 2016. Pada tahun 2014, rata-rata BOPO sebesar 93,33\% lalu pada tahun 2015 mengalami sedikit kenaikan menjadi 93,68\% dan pada tahun 2016 mengalami penurunan, tetapi kembali naik pada tahun 2017 dan pada tahun selanjutnya terus mengalami penurunan hingga tahun 2019 menjadi 92,77\%. Hal ini menunjukkan bahwa bank dapat menekan biaya operasional, sehingga rasio $\mathrm{BOPO}$ nya mengalami penurunan.

\section{Hasil Pengujian Data}

Hasil Uji Asumsi Klasik

Sebelum melakukan uji hipotesis maka terlebih dahulu perlu dilakukan uji asumsi klasik untuk mengukur ketepatan fungsi regresi dalam menaksir nilai aktualnya. Pengujian asumsi klasik terdiri dari:

\section{Normalitas}

Uji normalitas dilakukan untuk menguji apakah dalam model regresi, variabel pengganggu atau residual memiliki distribusi normal atau tidak. Untuk menguji apakah distribusi data normal atau tidak, ada dua cara untuk mendeteksinya, yaitu dengan analisis grafik dan uji statistik. Berikut ini adalah hasil uji normalitas dengan grafik histogram: 


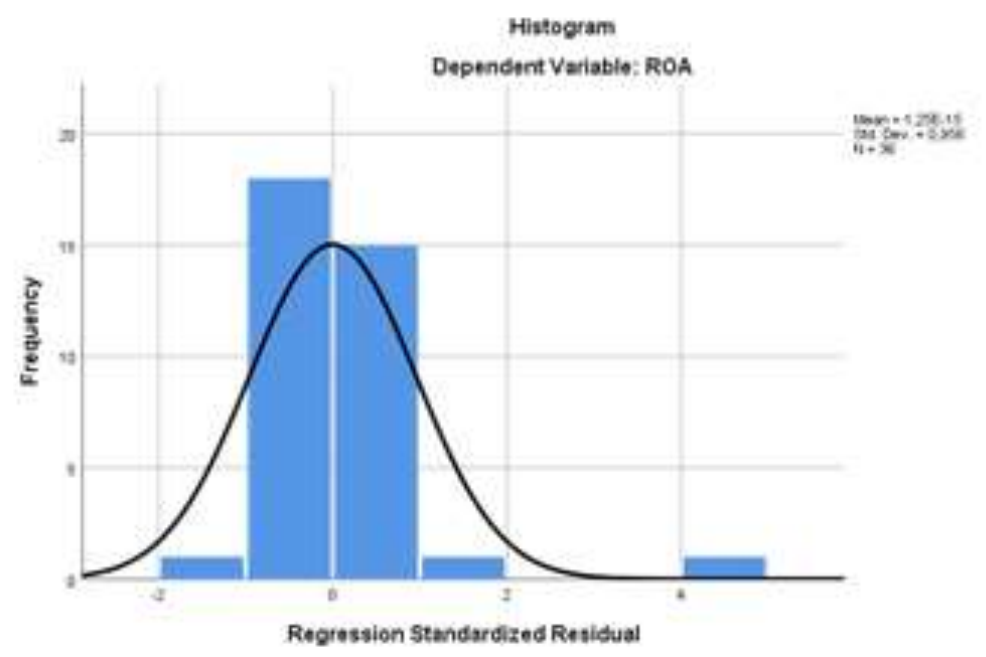

Financial Ratio of

Gambar 6. Grafik Histogram

Sumber: Data sekunder yang diolah

Dari Gambar 6. di atas, terlihat bahwa pola distribusi telah mendekati normal, akan tetapi kesimpulan yang diambil dengan hanya melihat dari grafik histogram dapat menyesatkan, khususnya untuk jumlah sampel yang kecil. Data dapat terlihat normal secara visual namun secara statistik bisa sebaliknya. Oleh karena itu perlu dilakukan analisis statistik dengan meggunakan uji kolmogorov-smirnov. Hasil pengujian normalitas dengan uji kolmogorov-smirnov dapat dilihat pada tabel berikut:

Tabel 7. Hasil Uji Kolmogorov - Smirnov

\begin{tabular}{llr}
\hline & & $\begin{array}{r}\text { Unstandardized } \\
\text { Residual }\end{array}$ \\
\hline $\mathrm{N}$ & & 36 \\
Normal Parameters & a,b & Mean \\
& Std. & 0,0000000 \\
& Deviation & 0,25727640 \\
Most Extreme & Absolute & \\
Differences & Positive & 0,221 \\
& Negative & 0,221 \\
Test Statistic & & $-0,148$ \\
Asymp. Sig. (2-tailed) & 0,221 \\
\hline
\end{tabular}

a. Test distribution is Normal.

b. Calculated from data.

c. Lilliefors Significance Correction.

Sumber: Data sekunder yang diolah

Berdasarkan hasil pengujian One-Sampel Kormogorov-Smirnov pada tabel 7. diatas, besarnya nilai test statistic kolmogorov smirnov adalah 0,221 dengan nilai Asymp. Sig (2tailed) $0,000<\alpha 0,05$. Dengan nilai asymp. Sig (2-tailed) yang kurang dari nilai $\alpha 0,05$ maka $\mathrm{HO}$ ditolak dan dapat dikatakan bahwa data yang digunakan dalam penelitian ini tidak terdistribusi dengan normal.

Menurut Ghozali $(2018$, 34) data yang tidak terdistribusi secara normal dapat ditransformasi agar menjadi normal. Oleh karena itu peneliti mentransformasi data variabel kedalam bentuk logaritma natural. Peneliti melakukan transformasi pada variabel Y dengan menggunakan logaritma natural, oleh karena itu maka hasil transform variabel $Y$ tersebutlah yang akan digunakan dalam uji normalitas dan berbagai uji lainnya dalam penelitian ini.

Berikut adalah pengujian ulang normalitas setelah dilakukan pengobatan data: 
Financial Ratio of Sharia Banking in Indonesia

\section{Gambar 7. Grafik Histogram Setelah Pengobatan Data Sumber: Data sekunder yang diolah}

Berdasarkan gambar 7. di atas, grafik histogram menunjukkan bahwa pola distribusi residual telah normal. Tetapi kesimpulan yang diambil dengan hanya melihat dari grafik histogram dapat menyesatkan, khususnya untuk jumlah sampel yang kecil. Data dapat terlihat normal secara visual namun secara statistik sebaliknya. Oleh karena itu perlu dilakukan juga analisis statistik dengan meggunakan uji kolmogorov-smirnov. Hasil pengujian ulang normalitas dapat dilihat pada tabel berikut:

Tabel 8. Hasil Uji Kolmogorov - Smirnov Setelah Pengobatan Data

\begin{tabular}{llr}
\hline & & $\begin{array}{r}\text { Unstandardized } \\
\text { Residual }\end{array}$ \\
\hline $\mathrm{N}$ & Mean & 35 \\
Normal & Std. & 0,0000000 \\
Parameters & a,b & 0,41170249 \\
& Deviation & \\
Most Extreme & Absolute & 0,085 \\
Differences & Positive & 0,064 \\
& Negative & $-0,085$ \\
Test Statistic & & 0,085 \\
Asymp. Sig. (2-tailed) &, $200^{\mathrm{C}, \mathrm{d}}$ \\
\hline
\end{tabular}
a. Test distribution is Normal.
b. Calculated from data.
c. Lilliefors Significance Correction.
d. This is a lower bound of the true significance.
Sumber: Data sekunder yang diolah

Berdasarkan hasil pada Tabel 8. di atas, menunjukkan bahwa data telah terdistribusi normal. Hal ini ditunjukkan dengan nilai Kolmogorov-Smirnov adalah 0,085 dan signifikansi pada 0,200 yang lebih besar dari 0,05 . Hal ini berarti data residual terdistribusi secara normal, karena nilai signifikansinya lebih dari 0,05 .

\section{Heteroskedastisitas}

Model regresi yang baik adalah yang homoskedastisitas atau tidak terjadi heteroskedastisitas. Terdapat berbagai cara untuk mendeteksi heteroskedastisitas, dua diantaranya adalah uji glejser dan uji scatterplot. Berikut Ini hasil uji scatterplot dari data penelitian: 


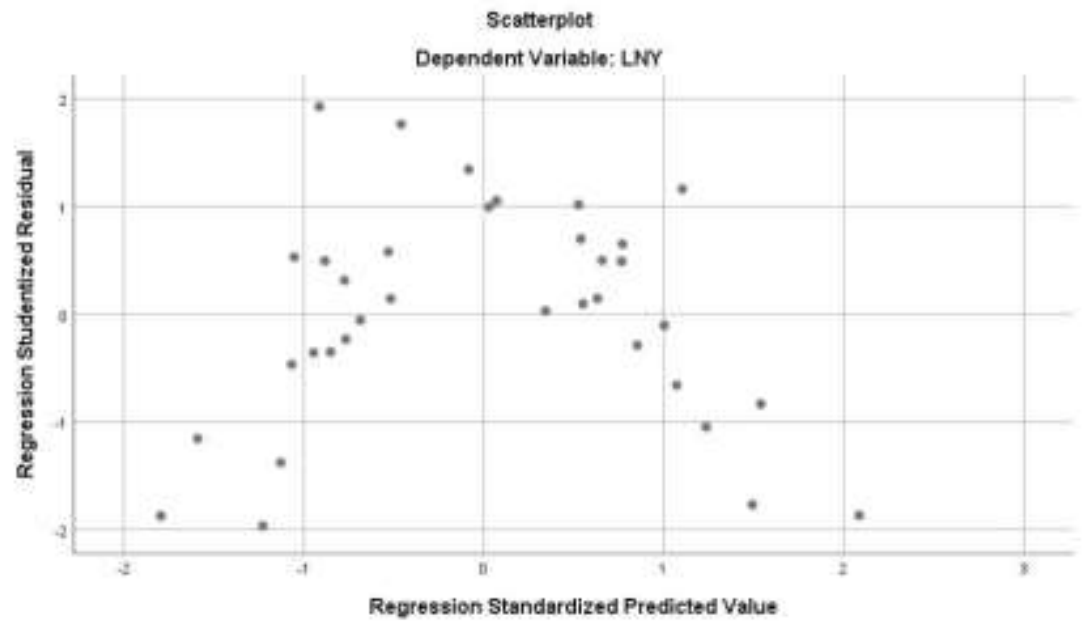

Financial Ratio of

Gambar 8. Hasil Uji Scatterplot

Sumber: Data sekunder yang diolah

Dari uji scatterplot pada gambar 8. tersebut, terlihat bahwa data telah menyebar secara acak di atas dan di bawah 0 pada sumbu Y, serta tidak membentuk pola tertentu yang teratur seperti bergelombang, melebar, kemudian menyempit, sehingga dapat disimpulkan bahwa tidak terjadi heteroskedastisitas. Kesimpulan ini juga diperkuat dengan hasil uji glejser yang hasilnya dapat dilihat sebagai berikut:

Tabel 9. Hasil Uji Glejser

\begin{tabular}{lcccrc}
\hline \multicolumn{7}{c}{ Coefficients $^{\mathbf{a}}$} \\
\hline \multicolumn{7}{c}{$\begin{array}{c}\text { Unstandardized } \\
\text { Coefficients } \\
\text { Std. }\end{array}$} & $\begin{array}{c}\text { Standardized } \\
\text { Coefficients }\end{array}$ & & \\
Model & B & Error & Beta & t & \multicolumn{1}{c}{ Sig. } \\
\hline 1 (Constant) & 1,384 & 0,968 & & 1,430 & 0,163 \\
CAR & $-0,006$ & 0,007 & $-0,164$ & $-0,873$ & 0,389 \\
FDR & $-0,006$ & 0,006 & $-0,200$ & $-1,145$ & 0,261 \\
BOPO & $-0,004$ & 0,009 & $-0,085$ & $-0,456$ & 0,652 \\
\hline
\end{tabular}

a. Dependent Variable: AbsUt

Sumber: Data sekunder yang diolah

Jika variabel independen signifikan secara statistik mempengaruhi variabel dependen, maka ada indikasi terjadi heteroskedastisitas. Hasil uji glejser pada tabel 4.4 di atas dengan jelas menunjukkan bahwa tidak ada satupun variabel independen yang signifikan secara statistik mempengaruhi variabel dependen nilai AbsUt. Hal ini terlihat dari nilai probabilitas signifikansinya di atas tingkat kepercayaan 5\%. Jadi dapat disimpulkan model regresi ini tidak mengandung adanya heteroskedastisitas.

\section{Multikolinearitas}

Model regresi yang baik seharusnya tidak terjadi korelasi diantara variabel independen. Untuk mendeteksi adanya multikolinearitas dapat dilihat dari nilai VIF dan tolerance pada masing-masing variabel seperti terlihat pada tabel berikut ini: 
Financial Ratio of Sharia Banking in Indonesia

$\underline{326}$
Tabel 10. Hasil Uji Multikolinearitas

\begin{tabular}{|c|c|c|c|c|c|c|c|}
\hline \multicolumn{8}{|c|}{ Coefficients $^{a}$} \\
\hline & $\begin{array}{l}\text { Unstand } \\
\text { Coeffi }\end{array}$ & $\begin{array}{l}\text { rdized } \\
\text { ents }\end{array}$ & $\begin{array}{c}\text { Standardiz } \\
\text { ed } \\
\text { Coefficient } \\
\text { s }\end{array}$ & & & $\begin{array}{l}\text { Colline } \\
\text { Statist }\end{array}$ & $\begin{array}{l}\text { arity } \\
\text { ics }\end{array}$ \\
\hline Model & $B$ & $\begin{array}{l}\text { Std. } \\
\text { Error }\end{array}$ & Beta & $\mathrm{t}$ & Sig. & $\begin{array}{c}\text { Toleran } \\
\text { ce }\end{array}$ & VIF \\
\hline 1 (Constant) & 11,573 & 1,698 & & 6,817 & 0,000 & & \\
\hline CAR & 0,027 & 0,011 & 0,182 & 2,358 & 0,025 & 0,849 & 1,177 \\
\hline FDR & 0,028 & 0,010 & 0,203 & 2,820 & 0,008 & 0,981 & 1,019 \\
\hline BOPO & $-0,163$ & 0,015 & $-0,812$ & $-10,559$ & 0,000 & 0,860 & 1,162 \\
\hline
\end{tabular}

a. Dependent Variable: LNY

Sumber: Data sekunder yang diolah

Berdasarkan tabel 10. di atas, maka dapat diketahui nilai VIF dan nilai tolerance untuk masing-masing variabel penelitian sebagai berikut :

1) Nilai VIF untuk variabel CAR sebesar $1,177<10$, sedangkan nilai tolerance sebesar $0,849>0,1$. Sehingga variabel CAR dinyatakan tidak terjadi gejala multikolinieritas.

2) Nilai VIF untuk variabel FDR sebesar $1,019<10$, sedangkan nilai tolerance sebesar $0,981>0,1$. Sehingga variabel FDR dinyatakan tidak terjadi gejala multikolinieritas.

3) Nilai VIF untuk variabel BOPO sebesar $1,162<10$, sedangkan nilai tolerance sebesar $0,860>0,1$. Sehingga variabel BOPO dinyatakan tidak terjadi gejala multikolinieritas. Sehingga dapat disimpulkan bahwa tidak ada ada multikolinearitas antar variabel dalam model regresi, karena hasil perhitungan nilai tolerance menunjukkan tidak ada variabel independen yang memiliki nilai tolerance kurang dari 0,10 dan hasil perhitungan VIF juga menunjukkan tidak ada variabel independen yang memiliki nilai lebih dari 10 .

\section{Autokorelasi}

Model regresi yang baik adalah regresi yang bebas dari autokorelasi. Untuk mengetahui ada tidaknya autokorelasi kita harus melihat nilai uji D-W. Perhatikan hasil uji Durbin Watson dibawah ini, nilai yang dibandingkan adalah:

\section{Tabel 11. Hasil Uji Durbin Watson} Model Summary ${ }^{b}$

\begin{tabular}{|c|c|c|c|c|}
\hline Model & $\mathrm{R}$ & $\begin{array}{r}\text { RAdjusted } \\
\text { SquareR Square }\end{array}$ & $\begin{array}{c}\text { Std. } \\
\text { Error of } \\
\text { the } \\
\text { Estimate }\end{array}$ & $\begin{array}{l}\text { Durbin- } \\
\text { Watson }\end{array}$ \\
\hline 1 & $918^{a}$ & 0,842 & 0,43116 & 1,113 \\
\hline
\end{tabular}

a. Predictors: (Constant), BOPO, FDR, CAR

b. Dependent Variable: LNY

Sumber: Data sekunder yang diolah

Berdasarkan tabel diatas, diketahui nilai DW sebesar 1,113 . Selanjutnya nilai ini akan dibandingkan dengan tabel durbin watson signifikansi $5 \%$, jumlah sampel $n=35$, dan jumlah variabel independen $3(\mathrm{k}=3)$. Besarnya DW-tabel: $\mathrm{dl}$ (batas luar) $=1,283 ; \mathrm{du}$ $($ batas dalam $)=1,653 ; 4-\mathrm{du}=2,347 ;$ dan $4-\mathrm{dl}=2,717$.

Dengan demikian dapat disimpulkan bahwa DW-test terletak pada daerah uji. Hal ini dapat dilihat pada Gambar 9. sebagai berikut: 


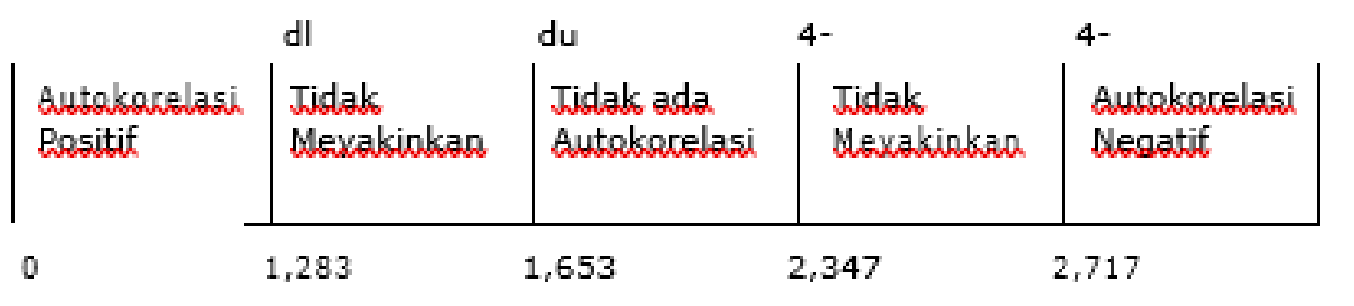

Gambar 9. Hasil Uji Durbin-Watson

Gambar 9 tersebut menunjukkan bahwa Durbin-Watson berada pada daerah autokorelasi positif. Sehingga perlu dilakukan pengobatan autokorelasi. Untuk mengobati autokorelasi, peneliti menggunakan metode cochrane orcutt. Berikut ini adalah hasil uji durbin watson setelah pengobatan autokorelasi.

\section{Tabel 12. Hasil Uji Durbin Watson Setelah Pengobatan Autokorelasi Model Summary}

\begin{tabular}{|c|c|c|c|c|c|}
\hline Model & $\mathrm{R}$ & $\begin{array}{r}\mathrm{R} \\
\text { Square }\end{array}$ & $\begin{array}{l}\text { Adjusted R } \\
\text { Square }\end{array}$ & $\begin{array}{l}\text { Std. Error } \\
\text { of the } \\
\text { Estimate }\end{array}$ & $\begin{array}{l}\text { Durbin- } \\
\text { Watson }\end{array}$ \\
\hline 1 &, $911^{a}$ & 0,830 & 0,813 & 0,39273 & 1,879 \\
\hline
\end{tabular}

a. Predictors: (Constant), Lag_X3, Lag_X2, Lag_X1

b. Dependent Variable: Lag_Y

Sumber: Data sekunder yang diolah

Berdasarkan tabel diatas, diketahui nilai DW sebesar 1,879 . Selanjutnya nilai ini akan dibandingkan dengan tabel durbin watson signifikansi $5 \%$, jumlah sampel $n=33$, dan jumlah variabel independen $3(\mathrm{k}=3)$. Besarnya DW-tabel: $\mathrm{dl}$ (batas luar) $=1,258 ; \mathrm{du}$ (batas dalam) $=1,651 ; 4-\mathrm{du}=2,349 ;$ dan $4-\mathrm{dl}=2,742$.

Dengan demikian dapat disimpulkan bahwa DW-test terletak pada daerah uji. Hal ini dapat dilihat pada Gambar 10. sebagai berikut:

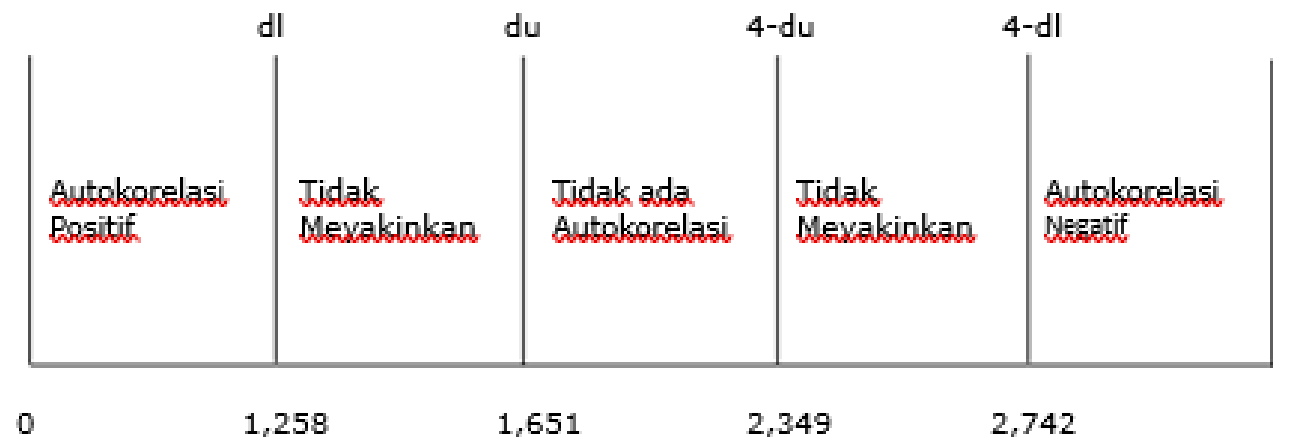

Gambar 10. Hasil Uji Durbin-Watson Setelah Pengobatan Autokorelasi

Gambar 10. tersebut menunjukkan bahwa Durbin-Watson berada pada daerah penerimaan hipotesis nol sehingga dapat disimpulkan bahwa tidak terdapat autokorelasi. Hasil uji autokorelasi ini juga diperkuat dengan hasil pengujian dengan uji run test yang dapat dilihat pada tabel berikut ini:

Financial Ratio of 
Financial Ratio of Sharia Banking in Indonesia

$\underline{328}$
Tabel 13. Hasil Uji Run Test

\begin{tabular}{lr}
\hline \multicolumn{2}{c}{ Runs Test } \\
\hline & $\begin{array}{c}\text { Unstandardized } \\
\text { Residual }\end{array}$ \\
\hline Test Value & 0,05658 \\
Cases < Test Value & 16 \\
Cases >= Test Value & 17 \\
Total Cases & 33 \\
Number of Runs & 13 \\
Z & $-1,411$ \\
Asymp. Sig. (2- & 0,158 \\
tailed) & \\
\hline a. Median &
\end{tabular}

Sumber: Data sekunder yang diolah

Berdasarkan hasil uji run test pada tabel 13.diatas, maka dapat disimpulkan bahwa data terbebas dari problem autokorelasi. Hal ini ditunjukkan dengan nilai uji run test sebesar 0,05658 dengan probabilitas 0,158 . Hal ini berarti data residual terbebas dari problem autokorelasi karena nilai signifikansinya lebih dari 0,05 .

\section{Hasil Regresi Linier Berganda}

Pengaruh variabel independen (CAR, FDR, dan BOPO) terhadap variabel dependen (ROA) dapat dianalisis menggunakan regresi linier berganda sebagai berikut:

Tabel 14. Hasil Regresi Linier Berganda

\begin{tabular}{|c|c|c|c|c|c|}
\hline \multicolumn{6}{|c|}{ Coefficients $^{a}$} \\
\hline \multirow[b]{3}{*}{ Model } & \multirow{2}{*}{\multicolumn{2}{|c|}{$\begin{array}{c}\text { Unstandardized } \\
\text { Coefficients } \\
\text { Std. }\end{array}$}} & \multirow{3}{*}{$\begin{array}{c}\text { Standardized } \\
\text { Coefficients } \\
\text { Beta }\end{array}$} & \multirow[b]{3}{*}{$\mathrm{t}$} & \multirow[b]{3}{*}{ Sig. } \\
\hline & & & & & \\
\hline & B & Error & & & \\
\hline 1 (Constant) & 11,573 & 1,698 & & 6,817 & 0,000 \\
\hline CAR & 0,027 & 0,011 & 0,182 & 2,358 & 0,025 \\
\hline FDR & 0,028 & 0,010 & 0,203 & 2,820 & 0,008 \\
\hline BOPO & $-0,163$ & 0,015 & $-0,812$ & $-10,559$ & 0,000 \\
\hline
\end{tabular}

a. Dependent Variable: LNY

Sumber: Data sekunder yang diolah

Berdasarkan hasil pengujian yang telah dilakukan, maka dapat ditulis persamaan regresi sebagai berikut:

$\mathrm{Y}=11,573+0,027 \mathrm{X} 1+0,028 \mathrm{X} 2-0,163 \mathrm{X} 3+\mathrm{e}$

Keterangan:

$\mathrm{Y}=$ Return On Assets

$\mathrm{X} 1=$ Capital Adequacy Ratio

$\mathrm{X} 2$ = Financing to Deposit Ratio

X3 = Beban Operasional Pendapatan Operasional e $=$ Error

Persamaan tersebut menunjukan bahwa nilai konstanta sebesar 11,573, hal tersebut menunjukkan bahwa ROA mempunyai nilai sebesar 11,573 apabila variabel independen (CAR, FDR, dan BOPO) tidak mengalami perubahan atau konstan. Nilai koefisien regresi Capital Adequacy Ratio (CAR) bertanda positif sebesar 0,027, nilai koefisien yang positif menunjukkan bahwa CAR berpengaruh positif terhadap ROA bank umum syariah, hal ini berarti bahwa setiap peningkatan satu nilai pada CAR, maka akan memberikan kenaikan sebesar 0,027 pada ROA. Nilai koefisien untuk Financing to Deposit Rasio (FDR) bertanda positif sebesar 0,028, nilai koefisien yang positif menunjukkan bahwa FDR berpengaruh positif terhadap ROA bank umum syariah, hal ini berarti bahwa setiap peningkatan satu nilai pada FDR akan memberikan kenaikan sebesar 0,028 pada ROA. Rasio Biaya Operasional Pendapatan Operasional (BOPO) bernilai -0,163, nilai koefisien yang negatif menunjukkan bahwa BOPO berpengaruh negatif terhadap 
ROA bank umum syariah, hal ini berarti bahwa setiap peningkatan BOPO adalah sebesar 1 satuan, maka akan menurunkan ROA sebesar 0,163.

Dengan demikian dapat disimpulkan bahwa hasil analisis pengaruh variabel independen terhadap variabel dependen yang dilakukan dengan regresi linier berganda tersebut telah sesuai dengan kerangka pemikiran yang diajukan oleh peneliti.

\section{Hasil Pengujian Hipotesis}

Selain uji asumsi klasik, juga dilakukan uji hipotesis yang dilakukan untuk mengukur ketepatan fungsi regresi dalam menaksir nilai aktualnya. Pengujian hipotesis dilakukan dengan melakukan pengujian secara parsial (uji t) maupun secara bersama-sama (uji F). Secara spesifik dapat dijelaskan sebagai berikut:

\section{Uji T}

Uji statistik t pada dasarnya menunukkan seberapa jauh pengaruh satu variabel penjelas/independen secara individual dalam menerangkan variasi variabel dependen. Hasil dari Uji t dapat dilihat pada tabel dibawah ini:

Tabel 15. Hasil Uji T Statistik

\begin{tabular}{|c|c|c|c|c|c|}
\hline \multicolumn{6}{|c|}{ Coefficients $^{a}$} \\
\hline & $\begin{array}{r}\text { Unsta } \\
\text { Coe }\end{array}$ & $\begin{array}{l}\text { rdized } \\
\text { ents }\end{array}$ & $\begin{array}{l}\text { Standardized } \\
\text { Coefficients }\end{array}$ & & \\
\hline Model & B & $\begin{array}{l}\text { Std. } \\
\text { Error }\end{array}$ & Beta & $\mathrm{t}$ & Sig. \\
\hline 1 (Constant) & 11,573 & 1,698 & & 6,817 & 0,000 \\
\hline CAR & 0,027 & 0,011 & 0,182 & 2,358 & 0,025 \\
\hline FDR & 0,028 & 0,010 & 0,203 & 2,820 & 0,008 \\
\hline BOPO & $-0,163$ & 0,015 & $-0,812$ & $-10,559$ & 0,000 \\
\hline
\end{tabular}

a. Dependent Variable: LNY

Sumber: Data sekunder yang diolah

1. Pengaruh variabel CAR terhadap ROA

Dari hasil penelitian variabel CAR memiliki nilai $t$ hitung sebesar 2,358 dengan signifikansi sebesar 0,025 dimana nilai signifikansi ini lebih kecil dari nilai signifikansi 0,05 . Artinya terdapat pengaruh yang signifikan dari CAR secara individual terhadap ROA.

2. Pengaruh variabel FDR terhadap ROA

Dari hasil penelitian variabel FDR memiliki nilai thitung sebesar 2,820 dengan signifikansi sebesar 0,008 dimana nilai signifikansi ini lebih kecil dari nilai signifikansi 0,05 . Artinya terdapat pengaruh yang signifikan dari FDR secara individual terhadap ROA.

3. Pengaruh variabel BOPO terhadap ROA

Dari hasil penelitian variabel BOPO memiliki nilai $t$ hitung sebesar - 10,559 dengan signifikansi sebesar 0,000 dimana nilai signifikansi ini jauh lebih kecil dari nilai signifikansi 0,05 yang artinya terdapat pengaruh yang signifikan dari BOPO secara individual terhadap ROA.

\section{Uji F}

Dilihat dari tabel 16. hasil perhitungan uji $\mathrm{F}$ dibawah ini, maka dapat diketahui bahwa F hitung sebesar 55,206 dengan nilai signifikansi sebesar 0,000. Hal ini berarti bahwa nilai probabilitas lebih kecil dari 0,05 sehingga $\mathrm{H} 0$ ditolak dan $\mathrm{H} 1$ diterima yang artinya bahwa variabel CAR, FDR, dan BOPO secara bersama-sama mempunyai pengaruh yang signifikan terhadap ROA.

Financial Ratio of 
Financial Ratio of Sharia Banking in Indonesia

\section{$\underline{330}$}

\begin{tabular}{|c|c|c|c|c|c|}
\hline \multicolumn{6}{|c|}{$\frac{\text { Tabel 16. Hasil Uji F Statistik }}{\text { ANOVA }^{\mathrm{a}}}$} \\
\hline Model & $\begin{array}{l}\text { Sum of } \\
\text { Squares }\end{array}$ & $\mathrm{df}$ & $\begin{array}{l}\text { Mean } \\
\text { Square }\end{array}$ & $\mathrm{F}$ & Sig. \\
\hline 1 Regression & 30,789 & 3 & 10,263 & 55,206 &, $000^{b}$ \\
\hline Residual & 5,763 & 31 & 0,186 & & \\
\hline Total & 36,552 & 34 & & & \\
\hline
\end{tabular}

a. Dependent Variable: LNY

b. Predictors: (Constant), BOPO, FDR, CAR

Sumber: Data sekunder yang diolah

\section{Koefisien Determinasi}

Uji koefisien determinasi dilakukan untuk mengukur seberapa jauh kemampuan variabel-variabel independen dalam menjelaskan variasi variabel dependen.

Tabel 17. Hasil Uji Koefisien determinasi

Model Summaryb

\begin{tabular}{llccc}
\hline & & \multicolumn{2}{c}{} & \multicolumn{2}{c}{$\begin{array}{c}\text { Std. Error } \\
\text { of the } \\
\text { Estimate }\end{array}$} \\
\hline 1 & $\mathrm{R}$ & Square & $\begin{array}{c}\text { Adjusted } \\
\text { R Square }\end{array}$ & 0,43116 \\
\hline
\end{tabular}

a. Predictors: (Constant), BOPO, FDR, CAR

b. Dependent Variable: LNY

Sumber: Data sekunder yang diolah

Berdasarkan hasil dari tabel 17. di atas nilai adjusted R Square sebesar 0,827. Hal ini berarti $82,7 \%$ variasi ROA dapat dijelaskan oleh variasi dari ketiga variabel independen CAR, FDR, dan BOPO. Sedangkan sisanya 17,3\% dijelaskan oleh variabel lain diluar penelitian ini.

\section{Pembahasan Hasil Penelitian}

Hasil dari pengujian hipotesis ternyata semuanya mendukung hipotesis. Pembahasannya adalah sebagai berikut:

\section{Pengaruh CAR terhadap ROA}

Capital Adequacy Ratio (CAR) disebut dengan rasio kecukupan modal, yang artinya besarnya modal yang dibutuhkan untuk menutupi risiko kerugian finansial yang mungkin timbul dari penggarapan aset yang berisiko. Semakin besar rasio ini maka keuntungan bank juga akan meningkat (Amelia, 2015, 232).

Hipotesis pertama menyatakan bahwa Capital Adequacy Ratio (CAR) berpengaruh positif terhadap Return on Asset (ROA). Dari hasil penelitian diperoleh nilai signifikansi sebesar 0,025 , sedangkan koefisien regresinya sebesar 2,358. Hasil pengujian hipotesis menunjukan bahwa CAR memiliki arah yang positif dan memiliki pengaruh yang signifikan terhadap ROA. Hal ini dapat dilihat dari nilai probabilitas CAR sebesar 0,025 dimana nilai signifikan ini lebih kecil dari nilai signifikansi 0,05 . Untuk koefisien regresi sebesar 2,358 berarti setiap kenaikan CAR sebesar 1\% akan meningkatkan ROA sebesar $2,358 \%$. Hal ini menunjukkan bahwa CAR berpengaruh positif dan signifikan terhadap ROA. Hasil penelitian ini mendukung hasil penelitian dari Wahyu Dwi Yulihapsari, Dien Noviany Rahmatika dan Jaka Waskito (2017) dimana pada penelitian yang mereka lakukan disimpulkan bahwa CAR berpengaruh positif dan signifikan terhadap ROA. Hasil dalam penelitian ini mengindikasikan bahwa semakin banyak modal yang dimiliki oleh bank umum syariah untuk menunjang aktiva yang mengandung atau menghasilkan risiko, maka bank tersebut akan dapat bertahan walaupun mengalami kerugian. Hal ini dapat membuat tingkat kepercayaan nasabah meningkat sehingga mereka tidak akan ragu untuk menyetorkan uang mereka pada bank umum syariah. Peningkatan simpanan nasabah pada bank umum syariah tersebut dapat berfungsi sebagai dana untuk diberikan 


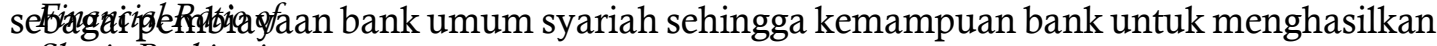

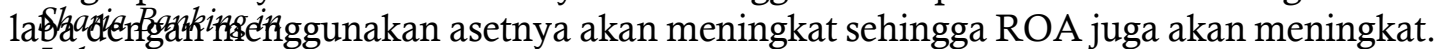
Denfgnesildemikian hipotesis pertama yang menyatakan bahwa Capital Adequacy Ratio memiliki pengaruh positif terhadap Return on Assets diterima.

\section{Pengaruh FDR terhadap ROA}

Menurut Widyaningrum dan Septiarini $(2015,974)$ dalam bank umum syariah, rasio FDR dapat mengukur tingkat efektivitas pembiayaan yang disalurkan oleh bank tersebut, sehingga jika rasio FDR meningkat maka laba bank juga akan meningkat dan meningkatkan ROA, dengan asumsi bahwa bank dapat menyalurkan pembiayaannya secara efektif.

3320tesis kedua menyatakan bahwa Financing to deposit Ratio (FDR) berpengaruh positif terhadap Return on Asset (ROA). Hasil pengujian hipotesis dua menunjukan bahwa FDR memiliki arah yang positif dan memiliki pengaruh yang signifikan terhadap ROA. Hal ini dapat dilihat dari nilai probabilitas FDR sebesar 0,008 dimana nilai signifikansi ini lebih kecil dari nilai signifikansi 0,05 . Untuk koefisien regresi sebesar 2,820 berarti setiap kenaikan FDR sebesar 1\% akan meningkatkan ROA sebesar 2,820\%. Hasil penelitian ini mendukung hasil penelitian dari Anisa Nur Rahmah (2018) yang menyatakan bahwa FDR berpengaruh positif dan signifikan terhadap ROA. Hasil dalam penelitian ini mengindikasikan bahwa bank umum syariah telah menyalurkan pembiayaannya secara efektif, sehingga semakin meningkat pembiayaan yang disalurkan oleh bank, maka profitabilitas yang diperoleh juga meningkat dan akan meningkatkan ROA. Dengan demikian hipotesis kedua yang menyatakan bahwa FDR berpengaruh positif terhadap Return on Asset (ROA) dapat diterima.

\section{Pengaruh BOPO terhadap ROA}

Rasio BOPO adalah perbandingan antara biaya operasional dan pendapatan operasional yang diperoleh oleh bank umum syariah. Rasio biaya operasional digunakan untuk mengukur tingkat efisiensi dan kemampuan bank dalam melakukan kegiatan operasinya (Margaretha, 2007, 62). Semakin kecil rasio ini, maka biaya operasional yang dikeluarkan bank semakin efisien sehingga kemungkinan bank dalam kondisi bermasalah juga menjadi semakin kecil. Semakin besar BOPO maka akan semakin kecil ROA bank, karena laba yang diperoleh bank juga menjadi kecil (Rahmah, 2018, 5). Hasil pengujian hipotesis tiga menunjukan bahwa BOPO memiliki arah yang negatif dan memiliki pengaruh yang signifikan terhadap ROA. Hal ini dapat dilihat dari nilai probabilitas BOPO sebesar 0,000 dimana nilai signifikan ini lebih kecil dari nilai signifikansi 0,05. . Untuk koefisien regresi sebesar -10,559 berarti setiap kenaikan BOPO sebesar 1\% akan menurunkan ROA sebesar 10,559\%. Sehingga BOPO memiliki pengaruh negatif signifikan terhadap ROA. Hasil temuan ini mendukung hasil penelitian Fajar Adiputra (2017) yang menyatakan bahwa BOPO berpengaruh negatif dan signifikan terhadap ROA. Hal ini menunjukkan bahwa peningkatan yang terjadi pada rasio BOPO bank menandakan adanya peningkatan proporsi beban operasional terhadap pendapatan operasional yang diterima oleh bank, dengan kata lain apabila biaya operasional mengalami kenaikan maka akan menurunkan laba sebelum pajak yang pada akhirnya akan menurunkan ROA pada bank yang bersangkutan, dengan demikian semakin besar BOPO maka akan semakin kecil ROA bank, karena laba yang diperoleh bank juga menjadi kecil. Hal ini mencerminkan adanya atau terjadinya ketidakefisienan kinerja operasional pada bank umum syariah. Dengan demikian hipotesis ketiga yang menyatakan bahwa BOPO memiliki pengaruh negatif terhadap ROA diterima.

\section{Pengaruh CAR, FDR, dan BOPO Secara Bersama-sama Terhadap ROA}

Rasio Return On Assets (ROA) digunakan untuk mengukur kemampuan manajemen bank dalam memperoleh keuntungan (laba) secara keseluruhan. Semakin besar ROA suatu bank, semakin besar pula tingkat keuntungan yang dicapai bank tersebut dan semakin baik pula posisi bank tersebut dari segi pengunaan aset (Margaretha, 2007, 61).
Financial Ratio of Sharia Banking in Indonesia 
Faktor-faktor yang dapat mempengaruhi ROA yaitu Capital Adequacy Ratio (CAR), Financing to Deposit Ratio (FDR), dan Biaya Operasional Pendapatan Operasional (BOPO). CAR menunjukkan seberapa besar modal bank untuk menunjang kebutuhannya dan semakin besar CAR maka akan semakin besar daya tahan bank yang bersangkutan dan menunjukkan semakin sehat bank tersebut (Wangsawidjaja, 2013, 116). FDR merupakan salah satu indkator kesehatan likuiditas bank. Penilaian likuiditas merupakan penilaian terhadap kemampuan bank untuk memelihara tingkat likuiditas yang memadai dan kecukupan manajemen rasio likuiditas. Semakin besar jumlah pembiayaan yang disalurkan oleh bank maka akan semakin rendah tingkat likuiditas bank yang bersangkutan. Namun di lain pihak, semakin besar jumlah pembiayaan yang diberikan, diharapkan bank akan mendapatkan return yang tinggi pula. (Wangsawidjaja, 2013, 117). Rasio Biaya Operasional adalah perbandingan antara biaya operasional dan pendapatan operasional (BOPO). Rasio biaya operasional digunakan untuk mengukur tingkat efisiensi dan kemampuan bank dalam melakukan kegiatan operasinya (Margaretha, 2007, 62). Hasil pengujian hipotesis empat menunjukan bahwa CAR, FDR, dan BOPO secara simultan memiliki pengaruh yang signifikan terhadap ROA. Hal ini dapat dilihat dari nilai probabilitas CAR, FDR, dan BOPO sebesar 0,000 dimana nilai signifikansi ini lebih kecil dari nilai signifikansi 0,05 . Hasil pengujian ini mendukung penelitian Sylvia Nurul Maulida (2015) yang menyatakan bahwa variabel-variabel independen CAR, FDR, dan BOPO berpengaruh secara bersama-sama terhadap ROA bank.

\section{PENUTUP}

Berdasarkan hasil analisis data dan pembahasan yang telah dikemukakan pada BAB IV, maka dapat ditarik beberapa kesimpulan, sebagai berikut:

1. Hasil penelitian dengan uji t menunjukkan bahwa terdapat pengaruh yang positif dan signifikan antara CAR terhadap ROA bank umum syariah. Hal ini dapat dilihat dari hasil pengujian secara parsial, variabel CAR memiliki nilai koefisien sebesar 2,358 dengan nilai probabilitas $0,030<0,05$.

2. Hasil penelitian dengan uji t menunjukkan bahwa terdapat pengaruh positif dan signifikan antara FDR terhadap ROA bank umum syariah. Hal tersebut dapat dilihat dari hasil pengujian secara parsial, variabel FDR memiliki nilai koefisien sebesar 2,820 dengan nilai probabilitas $0,008<0,05$.

3. Hasil penelitian dengan uji t menunjukkan bahwa terdapat berpengaruh negatif dan signifikan antara BOPO terhadap ROA Bank Umum Syariah. Hal tersebut dapat dilihat dari hasil pengujian secara parsial, variabel BOPO memiliki nilai koefisien sebesar $-10,559$ dengan nilai probabilitas $0,000<0,05$.

4. Dari hasil pengujian dengan uji $F$ diperoleh nilai $F$ hitung sebesar 55,206 dengan nilai signifikansi sebesar 0,000, karena nilai signifikansi jauh lebih kecil dari 0,05 maka variabel CAR, FDR, dan BOPO secara bersama sama berpengaruh terhadap ROA Bank Umum Syariah.

\section{DAFTAR PUSTAKA}

Abdalloh, I. (2018). Pasar Modal Syariah. Jakarta: Elex Media Komputindo.

Adiputra, F. (2017). Pengaruh CAR, NPF, FDR dan BOPO Terhadap Profitabilitas (ROA dan ROE) Pada Bank Umum Syariah [Skripsi]. Fakultas Ekonomi dan Bisnis. Universitas Islam Negeri Syarif Hidayatullah.

Akbar, T. (2019). Kajian Kinerja Profitabilitas Bank Umum Berdasarkan Kegiatan Usaha. Ponorogo: Uwais Inspirasi Indonesia.

Amelia, E. (2015). Financial Ratio And Its Influence To Profitability. Al-Iqtishad, 7(2): $229-240$. 
Ansofino, Jolianis, Yolamalinda, \& Arfilindo, H. (2016). Buku Ajar Ekonometrika. Yogyakarta: Deepublish.

Arifin, J., \& Syukri, M. (2006). Aplikasi Excel dalam Bisnis Perbankan Terapan.

Financial Ratio of Sharia Banking in Indonesia Jakarta: Elex Media Komputindo.

Arifin, Z. (2009). Dasar-Dasar Manajemen Bank Syariah. Jakarta: Azkia Publisher.

Bank indonesia. 2007. Surat Edaran Bank Indonesia no. 9/24/DPBS Sistem Penilaian Tingkat Kesehatan Bank Umum Berdasarkan Prinsip Syariah

https://www.bi.go.id/id/publikasi/peraturan/Pages/se_092407.aspx, diakses pada tanggal 19 November 2020

Bilian, F., \& Purwanto. (2017). Analisis Pengaruh CAR, NIM, BOPO, dan LDR Terhadap Profitabilitas Bank Persero. Journal of management studies, 2(1): 155-168.

Ghozali, I. (2018). Aplikasi Analisis Multivariate Dengan Program IBM SPSS 25 Semarang: Badan Penerbit Universitas Diponegoro. Gunawan, C. (2019). Regresi Linear Berganda . Sukabumi: Skripsi Bisa.

Hariwijaya, M. (2015). Metodologi dan Teknik Penuisan Skripsi, Tesis \& Disertasi. Yogyakarta: Parama Ilmu.

Hermawan, I. (2019). Metodologi Penelitian Pendidikan Kuantitatif, Kualitatif dan Mixed Methode. Kuningan: Hidayatul Quran Kuningan.

Hindarto, C. (2011). Analisis Pengaruh CAR, NIM, LDR, NPL, BOPO dan KAP terhadap Return On Assets (Studi Perbandingan pada Bank dengan Total Aset diatas 1 Trilyun dan dibawah 1 Trilyun Periode Tahun 2005-2008). Jurnal Bisnis Strategi, 20(2): 15-40.

Ismail. (2011). Perbankan Syariah. Jakarta: Prenadamedia.

Margaretha, F. (2007). Manajemen keuangan bagi industri jasa. Jakarta: Grasindo.

Maulida, S. N. (2015). Pengaruh CAR, FDR, dan BOPO Terhadap ROA Bank Umum Syariah (Studi Kasus Pada Bank Umum Syariah di Indonesia) [Skripsi]. Fakultas Syariah dan Ekonomi Islam. Institut Agama Islam Negeri Syekh Nurjati.

Munir, M. (2018) . Analisis Pengaruh CAR, NPF, FDR dan Inflasi terhadap Profitabilitas Perbankan Syariah di Indonesia. Journal of Islamic Economics, Finance, and Banking, 1(1\&2): 88-98.

Nisfiannoor, M. (2009). Pendekatan Statistika Modern untuk Ilmu Sosial. Jakarta: Salemba Humanika.

Nuha, V. Q., \& Mulazid, A. S. (2018). Pengaruh NPF, BOPO dan Pembiayaan Bagi Hasil terhadap Profitabilitas Bank Umum Syariah di Indonesia. Journal of Islamic Economics, 2(2): 168-182.

Otoritas Jasa Keuangan. 2020. Statistik Perbankan Syariah. www.ojk.go.id/id/kanal/syariah/data-dan-statistik/statistik-perbankansyariah/default.aspx, diakses pada tanggal 18 November 2020

Pinasti, W. F., \& Mustikawati, I. (2018). Pengaruh CAR, BOPO, NPL, NIM dan LDR Terhadap Profitabilitas Bank Umum Periode 2011-2015. Jurnal Nominal, 7(1): 126-142.

Pratiwi, D. D. (2012). Pengaruh CAR, BOPO, NPF dan FDR Terhadap Return On Assets (ROA) Bank Umum Syariah. (Studi Kasus pada Bank Umum Syariah di Indonesia Tahun 2005 - 2010) [Skripsi]. Fakultas Ekonomika dan Bisnis. Universitas Diponegoro.

Pratiwi, N. G. (2018). Analisis Pengaruh CAR, BOPO, NIM, NPF dan FDR Terhadap Profitabilitas Bank Syariah di Indonesia Tahun 2014-2016 [Skripsi]. Fakultas Ekonomi dan Bisnis. Universitas Muhammadiyah.

Putera, A. P. (2019). Hukum Perbankan. Surabaya: Scopindo Media Pustaka.

Rahmah, A. N. (2018). Analisis Pengaruh CAR, FDR, NPF, dan BOPO Terhadap Profitabilitas (Return On Assets) Pada Bank Syariah Mandiri Tahun 2013-2017 [Skripsi]. Fakultas Ekonomi dan Bisnis Islam. Institut Agama Islam Negeri Purwokerto.

Riyanto, S., \& Hatmawan, A. a. (2020). Metode Riset Penelitian Kuantitatif. Yogyakarta: Deepublish.

Sholihin, A. I. (2013). Buku Pintar Ekonomi Syariah. Jakarta: Gramedia Pustaka Utama.

Shomad, A. (2012). Hukum Islam Penormaan Prinsip Syariah Dalam Hukum Indonesia. Jakarta: Kencana. 
Financial Ratio of Sharia Banking in Indonesia

\section{$\underline{334}$}

Sitompul, S., \& Nasution, S. K. (2019). The Effect of Car, BOPO, NPF, and FDR on Profitability of Sharia Commercial Banks in Indonesia. BIRCI-Journal, 2(3): 234-238.

Suharyadi. (2004). Statistika untuk Ekonomi \& Keuangan Modern. Jakarta: Salemba Empat.

Syifa, A. (2018). The Impact of Non Performing Financing (NPF), Capital Adequacy Ratio(CAR), and Financing Deposit Ratio (FDR) To Return On Assets (ROA) with Depositor Funds As a Moderating Variable In Islamic Banks. Jurnal Akuntansi Berkelanjutan Indonesia, 1(2): 168-178.

Umar, H. (2003). Metode Riset Bisnis. Jakarta: PT. Gramedia Pustaka Utama.

Usman, R. (2009). Produk dan Akad Perbankan Syariah di Indonesia (Implementasi dan Aspek Hukum). Bandung: Citra Aditya Bakti.

Wangsawidjaja. (2013). Pembiayaan bank syariah. Jakarta: Gramedia Pustaka Utama.

Widyaningrum, L., \& Septiarini, D. F. 2015. Pengaruh CAR, NPF, FDR, dan OER Terhadap ROA Pada Bank Pembiayaan Rakyat Syariah di Indonesia Periode Januari 2009 Hingga Mei 2014. JESTT, 2(12): 970-985

Yanthiani, L. (2019). Pengaruh Non Performing Financing (NPF) dan Financing to Deposit Ratio (FDR) Terhadap Return On Assets (ROA) di PT. Bank Jabar Banten Syariah Kantor Pusat. Jurnal Akuntansi Bisnis dan Ekonomi, 5(1): 1293-1304.

Yulihapsari, W. D., Rahmatika, D. N., \& Waskito, J. (2017). Analisis Pengaruh Non Performing Financing (NPF), Capital Adequacy Ratio (CAR), Financing to Deposit Ratio (FDR), dan BOPO terhadap Profitabilitas (Studi Kasus pada PT. Bank Victoria Syariah Periode 2011-2016). Multiplier, 1(2): 102-114. 